\title{
Povaha a členění faktických úkonů realizovaných ze strany orgánů veřejné správy
}

\section{Nature and Systematic of Factual Acts Carried out by Authorities of Public Administration}

\author{
Pavel Všetička*
}

\begin{abstract}
Abstrakt
$\checkmark$ pröpadě faktických úkonu se jedná o značně rozsáblou matérii reprezentovanou mno ̌stvím rozličných

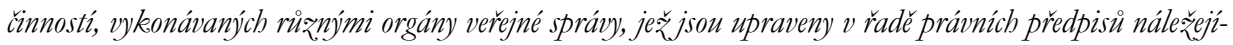
cich do rĩzných prámich odvétví, o jejiž systemizaci usiluje nauka již celá desetiletí. Obecně lze konstatovat, že rada otázek spojených s touto formou činnosti orgánů verejejné správy teprve čeká na podrobné védecké zpracováni. V rámci predkládaného prìspèvku jsem se zamèril na problematiku členèni faktických úkonù.

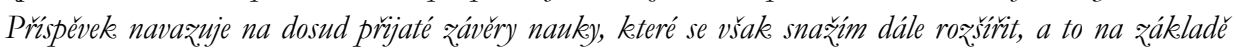
rizných konvergenčnich prvkì.
\end{abstract}

\section{Klíčová slova}

Bezprostrední zásaby; faktické pokyny; faktické úkony; faktické quasaby; verejná správa; zajištovací úkony.

\section{Abstract}

In the case of factual acts, this is a vastly extensive matrix represented by a number of different activities carried out by various public authorities, which are regulated by a series of legal acts belonging to different legal branches, whose systemization has been pursued for decades. Generally speaking, a number of issues related to this form of public administration activity are still waiting for detailed scientific work. In the framework of the present paper I focused on the issue of the division of factual acts. The contribution follows on to the conclusions of the doctrine, which I have already adopted, but which I try to extend further on the basis of various convergence elements.

\section{Keywords}

Immediate Interventions; Factual Instructions; Factual Acts; Factual Interventions; Public Administration; Hedging Operations.

\section{Úvod}

V rámci odborné literatury se lze běžně setkat s obecně přijímaným dvoustupňovým členěním faktických úkonů, prováděným v prvním stupni na základě způsobu, poprrípadě

\footnotetext{
* Mgr. Pavel Všetička, doktorand, Katedra správní vědy a správního práva, Právnická fakulta, Masarykova univerzita, Brno / Ph.D. student, Department of Administrative Studies and Administrative Law, Faculty of Law, Masaryk University, Brno, Czech Republic / E-mail: pavel.vseticka@seznam.cz
} 
účelu jejich realizace a v druhém stupni dle předmětu jejich působení či prostředků sloužících k jejich uskutečnění. ${ }^{1}$

Dle mého názoru však skrze toto dvoustupňové členění není možno ve všech souvislostech zcela komplexně postihnout tak rozsáhlou matérii, jakou faktické úkony představují. Osobně se domnívám, že faktické úkony je možno členit detailnějším zpơsobem, a to na základě dalších konvergenčních prvků.

Východiskem pro tvorbu předkládaného příspěvku je ověření hypotézy, jejímž obsahem je tvrzení, že systematika faktických úkonů uplatňovaná v současnosti v rámci vědy správního práva není, s ohledem na všechny atributy této formy realizace veřejné správy, vyčerpávající, a tudíž zde existuje prostor pro podrobnější členění předmětné matérie. Cílem prríspěvku je, v návaznosti na potvrzení stanovené hypotézy, nalezení dalších dělících kritérií, na základě jejichž aplikace bude možno faktické úkony členit detailnějším způsobem, než s jakým se lze setkat v rámci současné nauky.

\section{Povaha, znaky a vlastnosti faktických úkonů}

Faktické úkony se řadí mezi právní formy realizace veřejné správy. Sousloví „faktické úkony“ představuje právně teoretický pojem, jenž v sobě zahrnuje různé neformální činnosti právní povahy vykonávané na základě zákona ze strany orgánů veřejné správy. ${ }^{2,3} \mathrm{~V}$ rámci jednotlivých zákonů jsou tyto činnosti označovány různě, prostřednictvím rozličných zobecňujících termínů, zpravidla však jako úkony, ${ }^{4}$ zákroky, ${ }^{5}$

1 Viz např. HENDRYCH, D. a kol. Správní právo. Obecná cást. 9. vyd. Praha: C. H. Beck, 2016, s. 185-189; či MASAŘ́IK, J. a V. KRICNER Správníprávo. Obecná část. 7. vyd. Praha: Armex publishing, 2015, s. 79-80.

2 V dílech jednotlivých autorů se lze setkat s různým označením této formy realizace veřejné správy. Tak např. P. Průcha označuje tuto formu činnosti orgánů veřejné správy jako „Faktické úkony s př́mými právními důsledky“. Viz PRŮCHA, P. Správní právo. Obecná část. 8. vyd. Plzeň: Aleš Čeněk, 2012, s. 319. J. Staša v této souvislosti hovoří o „Faktických zásazích“. Viz HENDRYCH, D. a kol. Správní právo. Obecná cást. 9. vyd. Praha: C. H. Beck, 2016, s. 185; a E. Horzinková a Z. Fiala užívají pojmu „Faktické jednáni“. Viz HORZINKOVÁ, E. a Z. FIALA. Správni právo bmotné. Obecná cást. 2 vyd. Praha: Leges, 2015, s. 110.

3 Též v rámci rakouské literatury bývají tyto činnosti orgánů veřejné správy označovány různě. Nejčastěji však jako „bezprostřední správní donuceni““ či jako „faktické úřední jednáni“" nebo „projevy okamžitého policejního donuceni“" anebo „neformální správní akty“. Srov. KOJA, F. Einfübrung in das öffentliche Recht. 1. vyd. Wien: Orac, 1998, s. 104.

4 Dle $\ 10$ odst. 1 zákona č. 273/2008 Sb., o Policii České republiky, ve znění pozdějších předpisů (dále jen „zákon o policii“") se „úkonem“ rozumí veškerá ćinnost vykonávaná v rámci pravomoci policie, prostřednictvím které policisté a zaměstnanci policie zamezují ohrožení nebo porušení vnitřního pořádku a bezpečnosti, jehož odstranění spadá do úkolů policie.

5 Dle $\ 10$ odst. 5 zákona o policii představuje ,zákrok“ takový druh úkonu, při němž dochází k přímému vynucování splnění právní povinnosti nebo $\mathrm{k}$ prímé ochraně práv za použití síly nebo hrozby jejího použití. 
oprávnění ${ }^{6}$ či opatření ${ }^{7,8}$ anebo přímo prostřednictvím termínů vyjadřujících jejich faktickou povahu. ${ }^{9} \mathrm{Jak} v$ této souvislosti uvádí J. Staša „v pozitivním právu se pro různé správni úkony neformálni povaby použivaji rüzná označení, která však nemusi nic vypovidat o jejich teoretické povaze $e^{\text {“ }}{ }^{10} \mathrm{~J}$. Staša tímto naráží na absenci užívání právně-teoretických pojmů (jako např́klad faktické pokyny, zajišt'ovací úkony atd.) v rámci pozitivní právní úpravy.

Vzhledem k některým svým specifickým vlastnostem má tato forma realizace veřejné správy mezi ostatními právními formami činnosti orgánů veřejné správy poměrně „zvláštni““ postavení. Jak uvádí P. Průcha, v případě faktických úkonů „se jedná o mimorádnou formu realizace verejné správy, která v mimorádných situacích nastupuje namisto jiných právních forem realizace, zpravidla individuálnich správních aktu, nebo slouži k prómému vynuceni existujicí dobrovolně nesplnèné povinnosti."11 Z toho vyplývá, že faktické úkony zdaleka nepředstavují typickou podobu realizace veřejné správy a naplňování stanovených cílů prostřednictvím neformálních zásahů do právních poměrů svých adresátů není veřejné správě vlastní.

$\mathrm{Na}$ povahu faktických úkonů existují v teorii správního práva různé názory. Přičemž z hlediska nauky bývají tyto projevy veřejné správy považovány bud’ za specifické (reálné či neformálnî) správní akty ${ }^{12}$ či správní činnost sui generis. ${ }^{13}$

6 „Oprávnèním se obecně rozumi soubor opatreni, jejichž účel, jakož i divody a podminky pouřití jsou jednoznačně vymez̧eny zákonem“. HORZINKOVÁ, E. et al. Správni právo - zuláštni cást. Plzeň: Aleš Čeněk, 2009, s. 105. Např. zákon ČNR č. 555/1992 Sb., o Vězeňské a justiční stráži České republiky, ve znění pozdějších předpisů (dále jen ,zákon o vězeňské a justiční stráži‘) uživá pojmu „oprávnění příslušníka“, který zastřešuje dále konkretizovaná jednotlivá oprávnění př́islušníků vězeňské služby a justiční stráže.

7 Dle \ 5 zákona č. 146/2002 Sb., o Státní zemědělské a potravinářské inspekci a o změně některých souvisejících zákonů, ve znění pozdějších předpisů (dále jen „zákon o Státní zemědělské a potravinářské inspekci“) vydává inspektor Státní zemědělské a potravinářské inspekci vưči kontrolované osobě ,opatření".

$8 \mathrm{~V}$ případě termínu ,opatřeni“ se může ovšem jednat též o institut správního práva podobný faktickým úkonům, který ovšem pojmově nemusí v některých př́ípadech ani správní činností být. Srov. HENDRYCH, D. a kol. Správní právo. Obecná ćást. 9. vyd. Praha: C. H. Beck, 2016, s. 189. Např. dle $\int 7$ odst. 1 zákona ČNR č. 283/1991 Sb., o Policii České republiky, ve znění pozdějších předpisů (dále jen „starý zákon o policii“), byl policista povinen učinit ,jiná opatření“ nezbytná k provedení služebního zákroku nebo služebního úkonu, zejména vyrozumět nejbližší policejní útvar, byl-li páchán trestný čin nebo přestupek anebo bylo-li důvodné podezření z jejich páchání.

9 Např. „vydání a odebrání zbraně a prohlídka osoby“. Viz \35 zákona o policii.

10 STAŠA, J. Úvod do českého správního práva. 4. vyd. Praha: Policejní akademie České republiky, 2003, s. 88.

11 PRŮCHA, P. Správní právo. Obecná část. 8. vyd. Plzeň: Aleš Čeněk, 2012, s. 319.

12 Zatímco v rámci české literatury jsou faktické úkony považovány zpravidla za samostatnou a svébytnou formu realizace veřejné správy, rakouská správně-právní nauka považuje faktické úkony za specifický druh správních aktů, označovaných jako „bezprostřední př́kazy“ a „donucovací akty (činnosti)“. Rakouská nauka v této souvislosti uvádí, že specifickou vlastností bezprostředních př́kazů a donucovacích aktů je jejich neformálnost, přičemž v ostatních parametrech vykazují tyto formy realizace veřejné správy všeobecné znaky (individuálních) správních aktů. Jinak řečeno, rakouská správní nauka hovoří v souvislosti s faktickými úkony o tzv. neformálních správních aktech. Srov. KOJA, F. Einführung in das öffentliche Recht. 1. vyd. Wien: Orac, 1998, s. 104.

13 HENDRYCH, D. a kol. Správní právo. Obecná ćást. 9. vyd. Praha: C. H. Beck, 2016, s. 188. 
Jak již bylo zmíněno, vzhledem ke skutečnosti, že prostřednictvím realizace faktických úkonů oprávněné úřední osoby jednostranně zasahují do právních poměrů konkrétních, individualizovaných a jmenovitě určených adresátů veřejné správy, přičemž tyto úkony zároveň slouží $\mathrm{k}$,jednorázovému“ řešení pacifických situací spojených s aplikací práva, ${ }^{14}$ bývá $z$ hlediska správně-právní teorie zdůrazňována jejich podobnost s individuálními správními akty, namísto kterých bývají faktické úkony zpravidla vykonávány. ${ }^{15}$

V rámci nauky se lze setkat též s názorem, že některé neformální projevy veřejné správy se svojí povahou blíží spíše opatření obecné povahy. ${ }^{16} \mathrm{~V}$ případě bezprostředních omezení (spočívajících naprríklad v dočasném vyřazení veřejně obslužného zařízení z provozu) či faktických pokynů (např́iklad zákaz vstupu na určené místo) tyto rysy opravdu vysledovat lze, nebot’ v rámci řešení konkrétní věci dopadá působení těchto úkonů na neurčitý okruh adresátů.

Mimo to P. Průcha řadí právní prostředky mající povahu přímého donucení ke splnění právní povinnosti, tedy faktické úkony (konkrétně bezprostřední zásahy a úkony učiněné v rámci výkonu správní exekuce) mezi právní záruky, respektive záruky zákonnosti ve veřejné správě. ${ }^{17}$ Význam bezprostředních zásahů, zajišt'ovacích úkonů a exekučních úkonů jakožto záruk zákonnosti ve veřejné správě, spočívá především v jejich „schopnosti““ vynutit splnění dobrovolně nesplněné právní povinnosti. A to at' již právní povinnosti vynucené bez předchozího rozhodnutí př́islušného orgánu majícího povahu sankce za její porušení (např́iklad zabránění v narušování veřejného pořádku), tak právní povinnosti uložené rozhodnutím př́slušného orgánu veřejné správy (správní exekuce na nepeněžitá plněnî). Bezprostřední zásahy, zajišt’ovací úkony a exekuční úkony tedy představují právní nástroje, prostřednictvím kterých státní aparát zajišt'uje vymahatelnost svých rozhodnutí práva, jakož i primární ochranu zákonem chráněných zájmů (předcházející jejich sekundární ochraně mající podobu správních či soudních trestů), bez jejichž existence by byla veřejná moc „bezzubá“،

Faktické úkony lze obecně charakterizovat jako zvláštní skupinu právních forem činností vykonávaných ze strany orgánů veřejné správy, jejíž podstata spočívá v oprávnění

14 Srov. PRU゚CHA, P. Správní právo. Obecná část. 8. vyd. Plzeň: Aleš Čeněk, 2012, s. 278.

15 Faktické úkony se svojí povahou blíží individuálním správním aktům. Liší se však tím, že jim nepředchází správní řízení, respektive, že okamžik „,vydání“ aktu a jeho výkon spadá v jeden okamžik. Srov. SLÁDEČEK, V. Obecné správni právo. 3. vyd. Praha: Wolters Kluwer ČR, 2013, s. 189.

16 POMAHAČ, R. et. al. Verejná správa za rozcestím (právní reflexe). 1. vyd. Praha: Univerzita Karlova v Praze, Právnická fakulta, 2013, s. 46.

17 Viz PRŮCHA, P. Správní právo. Obecná část. 8. vyd. Plzeň: Aleš Čeněk, 2012, s. 324-325. 
na základě obecného ${ }^{18}$ či speciálního ${ }^{19}$ zákonného zmocnění zasáhnout, zpravidla bezprostředně, neformálně, avšak aspoň v obecných rysech zákonem předvídaným způsobem, ${ }^{20}$ s různým stupněm intenzity, do právních poměrů (nejčastěji ústavně zaručených práv a svobod) fyzických nebo právnických osob, jestliže je to při výkonu správního či dopravně-bezpečnostního dozoru nezbytné k uvedení konkrétních př́padů do souladu s normami správního práva, ${ }^{21}$ anebo jestliže je to nezbytné při výkonu policejně-bezpečnostních činností k ochraně významných zákonem chráněných zájmů, souhrnně označovaných jako tzv. „,policejní statky“, 22, 23 či k vynucení rozhodnutí některého z orgánů veřejné moci.

18 Obecné zákonné zmocnění je legislativně technicky tvořeno tak, že se do hypotézy právní normy vsunují výrazy (neurčité právní pojmy) jako např. „,veřejný pořádek“, „bezpečnost“, atd. Tyto výrazy vyjadřují ve zkratce stav, který existuje, jestliže jsou v podstatě dodržena pravidla chování lidí, která sice nejsou výslovně a podrobně vyjádřena v právní normě, jsou však právně závazná, nebot' je nutné je dodržovat podle obecného přesvědčení lidí v určitém čase a v určitém místě. Srov. LUKEŠ, Z. Základy bezpečnostního práva. Praha: ACADEMIA, 1971, s. 78.

19 „Speciálni zákonné zmocnèni je konstruováno tak, že v prǒslušné právni normè, z niž se toto żmocnèni odvozuje, je bypotéza formulována relativně určitě (konk rétnè), jednoznačně nebo taxativně, a tím je uváženi pri jeji aplikaci ponechán úzký prostor. Cím konkrétnèjsí je bypotéza právni normy, tím užši je prostor pro wváženi pri aplikaci právni normy a snažsi je koneckonců i prezkoumání, zda na jedné stranè byla správnè splnèna př̀slušná právni povinnost, a na drubé stranè, żda byl správný postup orgánu státni správy v prípadě nutnosti vymáháni této povinnosti“. LUKEŠ, Z. Základy bezpečnostního práva. Praha: ACADEMIA, 1971, s. 80.

20 Vzhledem $\mathrm{k}$ tomu, že zákonodárce není schopen předem předvídat veškeré situace, jejichž řešení bude v budoucnu vyžadovat neformální postup ze strany orgánů veřejné správy, jsou oprávnění k realizaci právních forem činností, jež mají z právně-teoretického hlediska podobu faktických úkonů, legislativně vyjádřeny v podobě obecných autorizačních doložek, či jinak řečeno generálních zmocňovacích klauzulí. Srov. MATES, P., J. ŠKODA a F. VAVERA. Veřjné sbory. 1. vyd. Praha: Wolters Kluwer ČR, 2011, s. 11 a 15. Nicméně přestože faktické úkony bývají z hlediska správně-právní teorie označovány za neformální projevy veřejné správy, musí i zde být dodrženy určité zákonné postupy. Srov. KINDL, M. et al. Základy spráuního práva. 2. vyd. Plzeň: Aleš Čeněk, 2009, s. 166. To znamená, že zákonodárce za účelem zamezení projevů libovůle ze strany aplikujících orgánů alespoň rámcově upravuje prostředky, které mohou být při realizaci těchto neformálních činností užity (např. obušek nebo jiný úderný prostředek), stejně jakož i v obecné podobě předvídá formu jejich provedení (např. hmaty a chvaty). Konkretizace často značně obecně vyjádřených prostředků a forem provedení faktických úkonů je ponechána na podzákonných právních předpisech jež mají nejčastěji podobu interních normativních instrukcí.

21 Srov. HEJDA, J. a K. PŘIBYL. Správní právo. České Budějovice: Vysoká škola evropských a regionálních studií, 2011, s. 89.

22 „Mezi tyto statky jou tradičně razeny ochrana státu, veřejná bezpečnost, bezpečnost osob a majetku, klid, mravnost, veréjné zdravi; jejich okruh se však stále rozruistá, a podat úplný výčet není s obledem na dynamiku dosti dobre možné a ostatně ani účelné. MATES, P., J. ŠKODA a F. VAVERA. Verejné sbory. 1. vyd. Praha: Wolters Kluwer ČR, 2011, s. 2.

23 Vymezením policejních statků se zabývala již prvorepubliková právní věda. Tehdejší literatura v této souvislosti uvádí několik neurčitých pojmů, jakými je např́iklad veřejný zájem, veřejné dobro či veřejná mravnost. S vědomím nutnosti výkladu těchto pojmů Slovník veřejného práva československého uvádí okomentovaný názor tehdejšího Nejvyššího správního soudu. „Veřejný pokoj a rád znamená jednak soubrn právních norem a norem etických a společenských, jejichžz zachováni podle dočasně panujicich obecných názorü je podminkou klidnébo a sporádanébo soužití, jednak stav společnosti onèm normám odpovidajici". $V$ definici této zachycen je právé jak onen element normativního rázu, jenž zastoupen jest v obratu zde vykládaném slovem ,rád“, tak i element rázu statusového, jenž odpovidá použitému zde slovu „pokoj", nad to pake tento poslednèjši výraz zákonný je vyložen ješté i v tom sméru, žze musí jit vždy o ochranu klidnébo a sporádanébo souřití. Př pojmech veréjný rád, klid apod. nejde o nic nejuristickébo, metajuristického, prirozenoprávníbo; právni rád recipuje pro sebe názory spolećenské a etickế. HÁCHA, J., J. HAVELKA, J. HOETZEL a K. LAŠTOVKA. Slovnik verejného práva československého. Svazek III. Brno: Polygrafia, 1934, s. 165. 
Přestože $\mathrm{k}$ realizaci faktických úkonů mohou být na základě zákona oprávněny různé orgány veřejné správy, ${ }^{24}$ je tato forma činnosti úzce spojena s plněním úkolů některých „zvláštních“ orgánů veřejné správy, ${ }^{25}$ souhrnně označovaných jako bezpečnostní (či veřejné $)^{26}$ sbory. To se týká především skupiny faktických úkonů označovaných jako tzv. „,bezprostřední zásahy““. ${ }^{27}$

Správně-právní nauka v souvislosti s vymezením obecných znaků faktických úkonů zdůrazňuje především jejich bezprostřední povahu. ${ }^{28}$ Bezprostřednost je možno v případě faktických úkonů vnímat ve dvou různých rovinách, jednak jako

a) požadavek na včasnost reakce ze strany př́slušného orgánu, za účelem snahy o zamezení maximálnímu množství škodlivých následků, jež mohou v důsledku okolností, které úkon vyvolaly, nastat, nebo jako

b) časové ohraničení možnosti zahájit úkon.

V prvním př́padě se jedná o rychlost reakce na vzniklé nebezpečí, protiprávní jednání či stav. Nicméně míra „bezprostřednosti“, s jakou jsou faktické úkony realizovány, se v rámci jednotlivých skupin faktických úkonů, ${ }^{29}$ tak i s ohledem na okolnosti konkrétního př́padu značně liší. Bezprostřednost ve smyslu požadavku na bezpodmínečně minimální časové rozpětí mezi okamžikem vzniku nebezpečí, protiprávního jednání či stavu a jeho eliminaci, př́padně rozhodnutím o realizaci úkonu a jeho uskutečněním

24 Např. dle $\int 8$ zákona ČNR č. 64/1986 Sb., o České obchodní inspekci, ve znění pozdějších předpisů může inspektor na základě zjištěného porušení právní povinnosti, která může mít za následek ohrožení života nebo zdraví spotřebitelů zakázat výkon další činnosti nebo nařídit uzavření provozovny až na dobu dvou prodejních nebo provozních dnů následujících po dni zjištění nedostatkư. Dále je třeba zmínit též veřejné stráže, jejichž členové jsou k této formě činnosti oprávněni na základě jednotlivých zvláštních zákonů, jež upravují jejich postavení a činnost. Srov. např. \39 odst. 2 písm. a) a c) zákona č. 289/1995 Sb., o lesích a o změně některých zákonů, ve znění pozdějších předpisů nebo ( 14 odst. 1 písm. a) b) c) e) a g) zákona č. 449/2001 Sb., o myslivosti, ve znění pozdějších předpisů.

25 Někteří autoři ( $z$ hlediska státovědného přístupu) označují tyto orgány veřejné moci jako tzv. „zvláštní složky“. Srov. FILIP, J. a J. SVATOŇ. Státověda. 5. vyd. Praha: Wolters Kluwer ČR, 2011, s. 57.

26 Termín „veřejné sbory“ užívá pro označení těchto orgánů veřejné správy ve svém stejnojmenném díle autorský kolektiv Mates, Škoda a Vavera. Srov. MATES, P., J. ŠKODA a F. VAVERA. Verejné sbory. 1. vyd. Praha: Wolters Kluwer ČR, 2011, 384 s.

27 „K definičnim znakuim veřejných sboru patrŭ, že s jejich činností je spojována možnost použiti donuceni ve smyslu násilného fyzickébo prinuceni k plnèni povinnosti nebo zabránèni a odvraceni od porušováni zákazu“. Ibid., s. 4.

$28 \mathrm{~V}$ prŕpadě faktických úkonů (zásahů) se jedná o bezprostřední reakci vykonavatele veřejné správy na aktuálně nastalé skutkové okolnosti. Srov. Ibid., s. 185.

29 Např. v př́padě faktických pokynů není zpravidla mezi rozhodnutím o udělení pokynu a jeho realizací výraznější časová prodleva. Naproti tomu v případě zajišt’ovacích úkonů či bezprostředních zásahů může (v př́padě že není bezprostředně ohrožen život nebo zdraví osob) následně po rozhodnutí o jejich uskutečnění, samotné realizaci předcházet (i několika hodinová) příprava spočívající v plánování zásahu či přivolání posil na místo atd. (např́klad vstup policistů do objektu kde se ukrývá nebezpečný pachatel nebo „vyklizení“ neoprávněně obývaného objektu tzv. squatu). 
bez ohledu na další okolnosti př́ípadu nelze pokládat za obligatorní pojmový znak faktických úkonů. ${ }^{30}$

Ve druhém př́ipadě se jedná o časovou přiměřenost úkonu. To znamená, že v př́ípadě realizace faktických úkonů musí nebezpečí, protiprávní jednání či stav bezprostředně hrozit nebo trvat. ${ }^{31}$

Dalším charakteristickým znakem faktických úkonů je jejich neformální povaha, což znamená, že ,jejich realizace neni výsledkem nèjakého formálního procesu a povinnost č oprávnèní je provést vzniká za urǔitých skutkových okolnosti prǐmo ze zákona“ ${ }^{32}$ Příslušné úřední osoby tudíž nejsou v procesu rozhodování o uskutečnění či neuskutečnění úkonu, jakož i při jeho případné realizaci vázány zákonnými požadavky kladenými na ř́zení, jehož výsledkem jsou individuální správní akty (potřeba dokazování skutkového stavu, o němž nejsou důvodné pochybnosti před vydáním rozhodnutí či možnost uplatnění ráaných opravných prostředků proti prvoinstančnímu rozhodnutí atd.). ${ }^{33}$

Postupy při provádění jednotlivých faktických úkonů nejsou upraveny obecným procesním předpisem určeným pro oblast výkonu veřejné správy, tj. zákonem č. 500/2004 Sb., správním řádem, ve znění pozdějších předpisů (dále jen „správní řád“), ${ }^{34}$ který jinak upravuje postupy při realizaci takřka všech ostatních právních forem činností uskutečňovaných ze strany správních orgánů v oblasti výkonu veřejné správy (mimo vydávání normativních správních aktů). Podobně je tomu i na hmotně-právní úrovni, kde faktické úkony z důvodu nepřeberného množství jejich forem není možno kodifikovat v rámci jediného právního předpisu, přičemž vzhledem k jejich účelové rozmanitosti dané odlišnou povahou jednotlivých oblastí veřejné správy, by takový záměr nebyl ani žádoucí.

Neformálnost faktických úkonů lze dle názoru J. Staši chápat v dvojím smyslu, a to tak, že:

a) nejsou výsledkem formalizovaného řízení,

b) rozhodnutí o jejich provedení a jejich realizace splývá v jediný úkon. ${ }^{35,36,37}$

30 Například zásah speciálního policejního útvaru (zásahové jednotky či útvaru rychlého nasazenî) jehož cílem je zadržení nebezpečných pachatelů mủže být za účelem překvapení plánován delší dobu i přesto, že policie ví, kde se hledané osoby nachází. Nicméně i v průběhu plánovaného a předem připravovaného zásahu mohou nastat nepředvídatelné okolnosti, na které je třeba pružně (bezprostředně) reagovat.

31 Srov. HENDRYCH, D. a kol. Správní právo. Obecná část. 9. vyd. Praha: C. H. Beck, 2016, s. 185.

32 Ibid., s. 187.

33 Procesní interakce není pojmovým předpokladem nástupu účinku faktických úkonů. Srov. Ibid., s. 185.

34 Vyjma správní exekuce na nepeněžitá plnění prováděné formou prrímého donucení ke splnění právní povinnosti. Srov. $\ 120$ až 128 správního řádu. Ale to ovšem pouze za předpokladu, že lze správní exekuci na nepeněžitá plnění mezi faktické úkony řadit. $\mathrm{K}$ tomuto tématu viz dále.

35 Srov. STAŠA, J. Úvod do českébo správního práva. 4. vyd. Praha: Policejní akademie České republiky, 2003, s. 88.

36 Srov. KINDL, M. et al. Základy spráuního práva. 2. upravené vyd. Plzeň: Aleš Čeněk, 2009, s. 168.

37 Srov. POMAHAČ, R. et. al. Veréná správa za rozcestím (práuní reflexe). 1. vyd. Praha: Univerzita Karlova v Praze, Právnická fakulta, 2013, s. 47. 
Z hlediska terminologie užívané v souvislosti s individuálními správními akty, jsou rozhodnutí o realizaci bezprostředních zásahů okamžitě pravomocná a vykonatelná. ${ }^{38} \mathrm{~V}$ případě realizace faktických úkonů je přrislušná úřední osoba orgánem oprávněným k vydání rozhodnutí a současně vykonavatelem tohoto rozhodnutí.

K tomu je ovšem nutno pripočíst ještě hmotně-právní neformálnost faktických úkonů, která se odráží v jejich podobě. Podobu faktických úkonů upravují jednotlivé zákony zpravidla jen velmi obecně, přičemž v jednotlivých případech uplatnění toho samého oprávnění se může jeho podoba značně lišit. ${ }^{39}$ E. Horzinková a Z. Fiala považují za projev neformálnosti též skutečnost, že faktické úkony bývají zpravidla realizovány mimo sídla správních úřadů. ${ }^{40}$

Přesto, že faktické úkony jsou z hlediska právní teorie označovány za neformální projevy veřejné správy, je třeba plně souhlasit s názorem M. Kindla, „že $i$ zde musi být dodrženy určité zákonné postupy. “41 To znamená, že orgány veřejné správy nemohou při realizaci faktických úkonů postupovat zcela libovolně, ale jsou vázány obsahem zákonného zmocnění i když to je, jak již bylo řečeno, zpravidla formulováno značně obecně. ${ }^{42}$

Nicméně $\mathrm{v}$ souvislosti $\mathrm{s}$ činností příslušníků bezpečnostních sborů mohou nastat situace, kdy prŕíslušné úřední osoby budou nuceny při ochraně svého života a zdraví, či života a zdraví jiných osob použít takové prostředky, které zákon v souvislosti s realizací správně-právních činností nepřipouští, ale které jsou př́ípustné v rámci jiných právních institutů, např. nutné obrany. Jinak řečeno, dochází zde k vzájemnému propojení dvou legálních prostředků určených pro ochranu zákonem chráněných zájmů, z nichž jeden je určen orgánům veřejné správy za účelem zajištění veřejného pořádku a bezpečnosti osob a majetku, a druhý komukoliv, což tedy za jistých okolností nevylučuje ani jeho uplatnění ze strany úředních osob při výkonu jejich pravomoci. ${ }^{43}$ Nicméně v této souvislosti vyvstává otázka, zda i v případě uplatnění nutné obrany ze strany úřední osoby se stále jedná o výkon veřejné správy.

38 Faktické úkony jsou zásadně účinné ihned. Srov. POMAHAČ, R. et. al. Veřejná správa za roz̧cestím (právní reflexe). 1. vyd. Praha: Univerzita Karlova v Praze, Právnická fakulta, 2013, s. 47.

39 Viz např. oprávnění policisty $\mathrm{k}$ realizaci donucovacího prostředku hmaty, chvaty, údery a kopy dle $\int 52$ písm. a) zákona o policii. Z logiky věci zákon a ani podzákonné právní předpisy nemohou konkrétní podobu tohoto oprávnění stanovit.

40 Srov. HORZINKOVÁ, E. a Z. FIALA. Spráuni právo bmotné. Obecná část. 2 vyd. Praha: Leges, 2015, s. 110.

41 KINDL, M. et al. Základy správního práva. 2. vyd. Plzeň: Aleš Čeněk, 2009, s. 166.

42 „I bezprocedurálni správni úkon je třeba v ákonem stanovených prǐpadech uskutečnovat predepsaným postupem (nižšího stupně formalizace, nežjakého dosabuje správni rízeni) nebo s volnèjšmi požadavky na vnèjš́ formu výsledku, nežje tomu u správnich aktưc. POMAHAČ, R. et. al. Verejná správa za roz̧cestím (právni reflexe). 1. vyd. Praha: Univerzita Karlova v Praze, Právnická fakulta, 2013, s. 46.

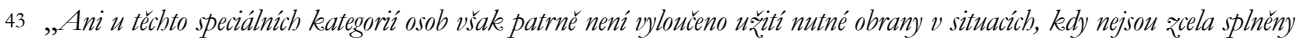
podminky opráunènébo použiti z̧braně. Jestliže je veden útok proti jejich životu či żdraví, neni na mistě jejich oprávnèni oproti jïným osobám zužovat. Ve svém jednáni by mèly být takové osoby omežny pouze obecnými podminkami nutné obrany, $i$ kedyž. by v konkrétním prípadě mély u sebe z̧brañ. KUCHTA, J. Nutná obrana. 1. vyd. Brno: MU, 1999, s. 72. 
Dle mého názoru v prrípadě, kdy jsou podle jiného právního předpisu splněny podmínky pro uplatnění nutné obrany či pomoci v nutné obraně, ${ }^{44} \mathrm{v}$ důsledku čehož jsou ze strany př́slušné úřední osoby použity takové prostředky, které zákon upravující jejich oprávnění nedefinuje, se jedná o projev veřejné správy, a to z toho důvodu, že právní povaha činnosti je v tomto př́padě vázaná na právní postavení úřední osoby, jakožto vykonavatele veřejné správy, nikoliv na z její strany vykonávanou formu činnosti. ${ }^{45,46}$

Obecně platí, že osoba, vůči které úkon směřuje, je povinna jej respektovat a podřídit se vưli úřední osoby, která úkon provádí, ${ }^{47,}{ }^{48}$ přičemž zákon v souvislosti s realizací faktických úkonů z logiky věci nepřipouští možnost uplatnění opravných prostředků, jež by disponovaly odkladným účinkem. Následně po jejich dokončení je možné se proti faktickým úkonům „bránit“ prostřednictvím stížnosti adresované prríslušnému orgánu veřejné správy, ${ }^{49}$ žaloby ve správním soudnictví, ${ }^{50}$ dále v případě, že prostřednictvím realizace faktického úkonu došlo k porušení základního ústavně zaručeného práva nebo svobody, je možné se proti tomuto úkonu (zásahu) bránit též podáním ústavní stížnosti, ${ }^{51}$ a nakonec, v prŕpadě, že v souvislosti s realizací faktického úkonu došlo ke spáchání trestného činu, stát poskytne oběti tohoto trestného činu ochranu $\mathrm{v}$ trestně-právní rovině. Využitím výše zmíněných právních prostředků sloužících k ochraně před nezákonnou činností (či nečinnostî) orgánů veřejné správy neformální

44 Viz \ 29 zákona č. 40/2009 Sb., trestního zákoníku, ve znění pozdějších předpisů (dále jen „,trestní zákoník").

45 Provedení faktického úkonu je vázáno na úřední osobu, se kterou je realizace této formy činnosti úzce spjata. Srov. HORZINKOVÁ, E. a Z. FIALA. Správníprávo hmotné. Obecná cást. Praha: Leges, 2010, s. 100.

46 Více k problematice uplatnění nutné obrany ze strany úředních osob v souvislosti s realizací bezprostředních zásahů viz VŠETIČKA, P. Uplatnění nutné obrany v souvislosti s realizací bezprostředních zásahů. Casopis pro právni védu a praxi [online]. 2018, roč. 26, č. 1, s. 135-148 [cit. 12. 10. 2018]. ISSN 1805-2789. Dostupné z: https://journals.muni.cz/cpvp/article/view/8416

47 Srov. HENDRYCH, D. a kol. Spráuní právo. Obecná cást. 9. vyd. Praha: C. H. Beck, 2016, s. 185.

48 „Občané jsou povinni podrobit se výkonu pravomoci veřejnébo činitele bez obledu na vlastni soukromý názor. Jsou-li présvédčení, צ̌e tímto jednáním bylo porušeno jejich právo či jïm byla způsobena škoda, mohou se proti takovému postupu verejnébo činitele bránit jiným qákonným zpisobem. Ústava, Listina ani žádná jiná práuni norma neprípouštěji, aby občané nejprve hodnotili zákonnost postupu verejných činiteli a teprve na základé toho jejich pokynu uposlechli nebo neuposlechli“. Usnesení Ústavního soudu ze dne 6. 1. 1998, sp. zn. I. ÚS 263/97.

49 Např́klad dle $\int 97$ odst. 1 zákona o policii může každý upozornit na nedostatky v činnosti policejního útvaru nebo konkrétního policisty. V př́ípadě, že zvláštní zákon ustanovení o možnosti podat stížnost neobsahuje, je možno využít obecného ustanovení o stížnosti dle \175 správního ráádu.

50 Viz \ 82 zákona č. 150/2002 Sb., soudního řádu správního, ve znění pozdějších předpisů, na základě něhož se může každý, kdo tvrdí, že byl přímo zkrácen na svých právech nezákonným zásahem, pokynem nebo donucením správního orgánu, který není rozhodnutím, a byl zaměřen přímo proti němu nebo v jeho důsledku bylo proti němu přímo zasaženo, může se žalobou u soudu domáhat ochrany proti němu nebo určení toho, že zásah byl nezákonný.

51 Viz \ 72 odst. 1 písm. a) zákona č. 182/1993 Sb., o Ústavním soudu, ve znění pozdějších předpisů. 
povahy, není nijak dotčeno právo na náhradu škody podle obecného ${ }^{52}$ či zvláštního právního předpisu. ${ }^{53,54}$

V průběhu realizace faktických úkonů je možno se proti nezákonnému postupu bránit pouze prostřednictvím nutné obrany. Nicméně jak v této souvislosti uvádí J. Staša, „tyto otázky nebyly dosud podrobnèji teoreticky rozpracovány". ${ }^{55}$ Možnost uplatnění nutné obrany proti zcela zjevně nezákonnému zásahu uskutečňovanému ze strany orgánu veřejné správy přichází $\mathrm{v}$ úvahu pouze $\mathrm{v}$ případě, kdy $\mathrm{v}$ souvislosti $\mathrm{s}$ jeho realizací dochází $\mathrm{k}$ bezprostřednímu ohrožení významných zákonem chráněných zájmů (zejména života či zdraví). Tedy nikoliv např́klad proti faktickým pokynům.

$\mathrm{Na}$ základě vymezení př́ćčin možných vad, jež se mohou $\mathrm{v}$ souvislosti s činností orgánů veřejné správy oprávněných k realizaci faktických úkonů vyskytnout, je možno, a to s ohledem na stupeň závažnosti a povahu těchto vad vedoucích $\mathrm{k}$ nezákonnosti postupu, faktické úkony (podobně jako individuální správní akty) rozdělit na napadnutelné a nicotné. ${ }^{56}$ Jestliže lze vzhledem k okolnostem a míře jeho nezákonnosti označit postup úřední osoby „pouze“ za napadnutelný, mají osoby, vưči kterým takový úkon směřuje povinnost se mu podrobit a teprve až následně po jeho dokončení mohou uplatnit ty prostř̌edky právní ochrany, které jim zákon pro tyto př́ípady dává $\mathrm{k}$ dispozici. ${ }^{57}$

Dle současného převažujícího názoru lze použití nutné obrany proti faktickým úkonům připustit pouze $\mathrm{v}$ prŕpadě, kdy jsou tyto úkony postiženy takovými vadami, které je zbavují povahy projevů veřejné správy, čímž je činí nicotnými. Konkrétně se jedná o absolutní věcnou nepříslušnost (nedostatek pravomoci) zasahující osoby, dále jsou to př́ípady, kdy k realizaci úkonu chybí zákonné zmocnění anebo prostřednictvím realizace úkonu dochází ke spáchání trestného činu. ${ }^{58,59}$

52 Viz \ 13 zákona č. 82/1998 Sb., o odpovědnosti za škodu způsobenou při výkonu veřejné moci rozhodnutím nebo nesprávným úředním postupem a o změně zákona České národní rady č. 358/1992 Sb., o notářích a jejich činnosti, ve znění pozdějších předpisů.

53 Viz $\int 95$ odst. 1 zákona o policii.

54 Více $\mathrm{k}$ problematice prostředků právní ochrany proti nezákonnému postupu či nezákonné nečinnosti ze strany orgánů veřejné moci v souvislosti s realizací faktických úkonů viz VŠETIČKA, P. Zásada přiměřenosti a zásada iniciativy při realizaci bezprostředních zásahů uskutečňovaných ze strany Policie České republiky z hlediska teorie a praxe. Casopis pro právní védu a praxi [online]. 2018, roč. 26, č. 3, s. 517-545 [cit. 12. 10. 2018]. ISSN 1805-2789. Dostupné z: https://journals.muni.cz/cpvp/article/view/9547

55 HENDRYCH, D. a kol. Správní právo. Obecná cást. 9. vyd. Praha: C. H. Beck, 2016, s. 188.

56 Srov. „Tato u nás málo prozkoumaná problematika má svou obdobu v teorii správního rozhodnutí (rozlišeni mezi rozhodnutimi sice vadnými, pro něž však plati presumpce právnosti, dokud nejsou žrušena, a roz̧̧odnutími nicotnými, na něž se pro záva:̌nost jejich vad bledí, jako kedyby vỉbec nebyla ǚmèna)". Ibid., s. 487.

57 „Mluvit v souvislosti s bezprostredními zásaby o opravných prostredcich je nepresné a iluzorní, nebot'smèruji proti stavu, který již existuje a jen výjimečnè jej lž zrušit nebo żmènit, notabene beze zbytku odstranit a odčinit jeho neprǐznivé následky". NOVÝ, D. Právní záruky a prostředky ochrany před policejními zásahy. Právní rádce, 2005, č. 10, s. 41.

58 Srov. SOLNǍ̌, V., J. FENYK a D. CÍSAŘOVÁ. Základy trestni odpovédnosti. 1. vyd. Praha: Orac, 2003, s. 150; dále srov. HENDRYCH, D. a kol. Správní právo. Obecná cást. 9. vyd. Praha: C. H. Beck, 2016, s. 487.

59 Více k problematice uplatnění nutné obrany proti nezákonnému zásahu ze strany orgánů veřejné moci viz VŠETIČKA, P. Uplatnění nutné obrany v souvislosti s realizací bezprostředních zásahů. Časopis pro právni védu a praxi [online]. 2018, roč. 26, č. 1, s. 135-148 [cit. 12. 10. 2018]. ISSN 1805-2789. Dostupné z: https://journals.muni.cz/cpvp/article/view/8416 
Přesto, že se v př́padě faktických úkonů jedná o neformální projevy veřejné správy, je jejich realizace ovládána některými právními zásadami. Přičemž by bylo možno říci, že právě z důvodu značné obecnosti jednotlivých zákonných zmocnění je uplatnění obecných právních zásad v případě faktických úkonů o to naléhavější. Požadavky kladené na bezvadnost faktických úkonů (naplnění podmínky zákonnosti, přiměřenosti, subsidiarity atd. ${ }^{60}$ jsou definovány právě prostřednictvím právních zásad, kterými je tato forma realizace veřejné správy ovládána. To se týká především bezprostředních zásahů, prostřednictvím jejichž realizace dochází k omezení základních práv a svobod a to zpravidla za použití fyzické síly.

Názor na to, zda se na faktické úkony vztahují základní zásady činnosti správních orgánů, se různí. Zatímco např́klad S. Skulová uvádí, že „správni rád se zpravidla nevz̨tabuje na nejri̊neèjsi tzv. faktické úkony (vyjma základnich zásad činnosti správnich orgánui) “. ${ }^{61,62} \mathrm{~V}$ důvodové zprávě ke správnímu řádu se uvádí, že ,základni zásady činnosti správních orgánu se uplatní na veškeré postupy správnich orgánu prì výkonu verejné správy, a to i v prípadè, že zulástni úprava vylouč pouřiti správního rádu jako celku. Z povaby véci ovšem vyplývá, že správní rád se nepoužije na tzu. bezprostredni zásaby“. ${ }^{33}$ Osobně se jednoznačně přikláním k prvnímu názoru, a to především s ohledem na $\int 177$ odst. 1 správního řádu, z jehož obsahu vyplývá, že působnost základních zásad činnosti správních orgánů přesahuje působnost samotného správního řádu. ${ }^{64}$

Mimo to lze ovšem působnost základních zásad činnosti správních orgánů ve vztahu $\mathrm{k}$ faktickým úkonům dovodit i jinou cestou. A to tak, že právní závaznost základních zásad činnosti správních orgánů vychází přímo z ústavních principů, jimž je podřízena veškerá činnost všech orgánů veřejné moci. ${ }^{65} \mathrm{~V}$ tomto smyslu se jedná o zásadu

60 Viz např. HENDRYCH, D. a kol. Správní právo. Obecná část. 9. vyd. Praha: C. H. Beck, 2016, s. 187.

61 SKULOVÁ, S. a kol. Správní právo procesní. 3. vyd. Plzeň: Aleš Čeněk, 2017, s. 26.

62 „Faktické zásaby se vymykaji blǐ̌ši procesni úpravě. I pro ně však plati zákeladni zásady činnosti vykonavatelù verejné správy (naše pozitivni právo je vyjadŕuje jen žçásti, a to v ćásti pruni správního rádu)“. POMAHAČ, R. et. al. Veřejná správa za rozuestím (právní reflexe). 1. vyd. Praha: Univerzita Karlova v Praze, Právnická fakulta, 2013, s. 47.

63 Důvodová zpráva k zákonu č. 500/2004 Sb., správní řád, ze dne 6. 2. 2003. In: ASPI [právní informační systém]. Wolters Kluwer ČR [cit. 14. 11. 2018].

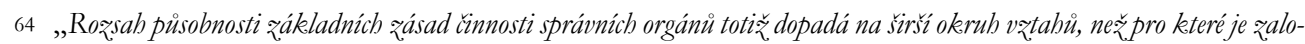
žena puisobnost správního rádu. Stalo se tak výslovně na základě \ 177 odst. 1 správního rádu. Základni zásady činnosti, resp. zejména ty ze základnich zásad, jež upravuji vz̧tah správnich orgánu k adresátům puisobeni verejné správy, je proto nutno vztáhnout napríklad také na normotvornou činnost správnich orgánů (véetnè vydáváni obecnè závazných vyblásek. a nařzeni obci a kraju), a také na tə̧v. faktické úkony správnich orgánu“. SKULOVÁ, S. a kol. Správni právo procesní. 3. vyd. Plzeň: Aleš Čeněk, 2017, s. 37-38.

65 Závaznost základních zásad činnosti správních orgánů se dovozuje z toho, že se jedná o obecné právní zásady vyplývající např́klad i z ústavního pořádku a mezinárodních smluv, kterými je Česká republika vázána a které mají přednost před zákonem. Srov. JEMELKA, L., K. PONDĚLÍČKOVÁ a O. BOHADLO. Správni rád. Komentár. 5 vyd. Praha: C. H. Beck, 2016, s. 22. 
zákonnosti, ${ }^{66}$ zásadu proporcionality (přiměřenosti), ${ }^{67}$ zásadu legitimního očekávání (rovnosti zacházení a zákazu diskriminace). ${ }^{68}$ Mimo zásad, přímo kopírujících ústavní principy, se na faktické úkony vztahují ještě některé další zásady, které jsou z výše zmíněných zásad odvozeny nebo pozitivně vyjádřeny v textech jednotlivých právních předpisů, upravujících oprávnění příslušných orgánů. Jedná se o zásadu zákazu zneužití správního uvážení (zásada legality vs. zásada oportunity), ${ }^{69,70}$ a zásadu veřejné správy jako služby (zásada iniciativy). ${ }^{71,72}$

Nakonec je třeba zmínit právní zásady, které mají svůj základ v právním řádu, ${ }^{73}$ nicméně jejich existence vyplývá ze samotného poslání, rozsahu pravomocí a působnosti,

66 Viz čl. 2 odst. 3 Ústavního zákona č. 1/1993 Sb., Ústavy České republiky, ve znění pozděǰš́ch předpisů (dále jen „Ústava“) a čl. 2 odst. 2 Usnesení předsednictva ČNR č. 2/1993 Sb., o vyhlášení Listiny základních práv a svobod jako součásti ústavního pořádku České republiky, ve znění pozdějších předpisů (dále jen „Listina“), kde se uvádí, že státní (veřejnou) moc lze uplatňovat jen v prrípadech a v mezích stanovených zákonem a to pouze způsobem, který zákon stanoví.

67 Viz čl. 4 odst. 4 Listiny, kde se uvádí, že při používání ustanovení o mezích základních práv a svobod musí být šetřeno jejich podstaty a smyslu a tato omezení nesmějí být zneužívána $\mathrm{k}$ jiným účelům, než pro které byla stanovena. Přiměřenost při realizaci bezprostředního zásahu se týká prostředků zvolených $\mathrm{k}$ uskutečnění zásahu a způsobu jejich užití. Mimo to je třeba zohlednit též časovou přiměřenost zásahu, to znamená, že zásah může být uskutečněn pouze $\mathrm{v}$ době, kdy nebezpečí bezprostředně hrozí anebo př́padné protiprávní jednání trvá. Srov. HENDRYCH, D. a kol. Správní právo. Obecná část. 9. vyd. Praha: C. H. Beck, 2016, s. 187. Zásada přiměřenosti je ve vztahu k jednotlivým formám bezprostředních zásahů zpravidla konkretizována $\mathrm{v}$ př́slušném zákoně. Viz nap̌r. \11 zákona o policii.

68 Cílem této zásady je zabránit libovůli prúi rozhodovací činnosti orgánů veřejné správy. Avšak na rozdíl od zásady legitimního očekávání, která zohledňuje skutkovou stránku př́padu, zásada rovnosti zacházení a zákazu diskriminace se vztahuje $\mathrm{k}$ objektům, vǔči nimž je rozhodovací pravomoc uplatňována, tedy adresátům veřejnoprávního působení. Srov. čl. 3 odst. 1 Listiny, kde se uvádí, že ,základní práva a svobody

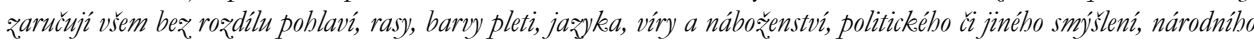
nebo sociálního piovodu, prišlušnosti ke národnostni nebo etnické mensinè, majetku, rodu nebo jinébo postaveni".

69 Institut správního uvážení je tradičně spojován především s rozhodovací činností správních orgánů, jejímž výsledkem je vydávání individuálních správních aktů. Nicméně $\mathrm{v}$ př́padě realizace bezprostředních zásahů musí př́slušný orgán veřejné správy (typicky prŕslušník bezpečnostního sboru) taktéž na základě správního uvážení rozhodnout o tom, zda daný zákrok provést či nikoliv, a dále rozhodnout o použití jednoho $\mathrm{z}$ několika možných prostředků, které mu zákon pro řešení nastalé situace dává $\mathrm{k}$ dispozici. „Výsledkem vzájemného vyvažováni zásady iniciativy a zásady prïměrenosti mữ̌e být s obledem na okolnosti

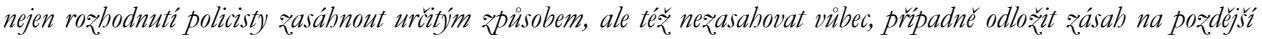
dobu. "Rozsudek Nejvyššího správního soudu ze dne 25. 5. 2015, č. j. 6As 255/2014-42.

70 Srov. LUKEŠ, Z. Základy bępeěnostního práva. 1 vyd. Praha: ACADEMIA, 1971, s. 83-85.

$71 \mathrm{~V}$ souvislosti s realizací faktických úkonů se jedná o povinnost provést úkon $\mathrm{v}$ př́padě, kdy dojde $\mathrm{k}$ nezákonnému zásahu do zákonem chráněných práv a svobod osob, jimž na základě zákona poskytují tyto orgány ochranu. Orgány veřejné správy odpovídají za škodu, která vznikne osobám v důsledku rozhodnutí těchto orgánů zákrok či úkon neprovést. Viz např. \11 písm. b) zákona o policii.

72 Některé $z$ těchto zásad (např. zásada přměřenosti či zásada iniciativy) jsou pozitivně vyjádřeny př́mo v rámci jednotlivých zvláštních zákonů upravujících oprávnění orgánů veřejné správy, jež mají povahu faktických úkonů. S ohledem na povahu faktických úkonů se nejčastěji jedná o zásadu přměřenosti. Viz např. $\int 11$ zákona o policii.

73 Viz čl. 3 Ústavního zákona č. 110/1998 Sb., o bezpečnosti České republiky, ve znění pozděǰ̌śch předpisů. 
jakož i povahy úkolů těch orgánů, které jsou za účelem zajištění veřejného pořádku a bezpečnosti osob a majetku oprávněny zasahovat prostřednictvím použití fyzického donucení do právních poměrů adresátů veřejné správy (bezpečnostní sbory). $\mathrm{V}$ tomto prŕpadě se jedná především o zásadu subsidiarity.

V souvislosti s působností správního ráádu ve vztahu k faktickým úkonům je třeba zmínit též ustanovení o stížnosti, a to v prrípadě kdy zvláštní zákon podobné ustanovení neobsahuje. ${ }^{74}$

Základní problém $z$ hlediska vědeckého přístupu $\mathrm{k}$ této formě činnosti orgánů veřejné správy spočívajícího ve snaze o její zpřehlednění prostřednictvím kategorizace jejich jednotlivých složek představuje skutečnost, že v prrípadě faktických úkonů se jedná o značné množství rozličných činností, vykonávaných různými orgány veřejné správy, ${ }^{75}$ jež jsou upraveny (roztroušeny) v řadě jednotlivých zvláštních zákonů náležejících do různých právních odvětví. ${ }^{76} \mathrm{Jak} v$ této souvislosti uvádí P. Mates a M. Starý ,jde o nesmírně bohatou škálu úkonu, o jejichž systemizaci usiluje nauka jižz celá desetiletí, aniž se prozatím podarilo nalézt pevná dèlici kritéria pro jejich rozhraničeni. Mimo jiné i proto, že počet, resp. druby tèchto úkonü, se neustále rozširuji. Jak patrno, podat zcela vyčerpávajici prebled těchto forem činnosti veřejné správy je prakticky nemožné, mimo jiné văhledem k tomu, že se mưžeme setkat s nejrĩznèjsimi hraničnimi, vájemnè se prekerývajicimi prōpady. Záležzi též na kritériich, podle nichž se členèni provádí, a na dalšich okolnostech. " 77 A právě otázka nastavení jasných dělících kritérií, jakož i zavedení jednotné terminologie ve vztahu k této formě realizace veřejné správy je dle mého názoru pro její zpřehlednění a rozčlenění zcela zásadní.

Pokud jde o členění neformálních projevů veřejné správy, zde je třeba poznamenat, že okruh neformálních činností právní povahy, spočívajících $\mathrm{v}$ bezprostřední reakci na zákonem predvídanou situaci, či sloužících $\mathrm{k}$ zajištění průběhu formalizovaného (zpravidla soudního řízenî) při nichž dochází k omezení práv a svobod osob, k jejichž realizaci jsou příslušné orgány veřejné správy, v některých případech výkon veřejné správy

74 Např́klad stížnost na postup strážníka obecní policie, který má povahu faktického úkonu, je možno podat dle obecné úpravy vyjádřené v \175 správního ráádu.

$75 \mathrm{~K}$ realizaci faktických úkonů jsou na základě různých zákonů oprávněny jak orgány státní správy, tak i některé orgány samosprávy (typicky obecní policie). „Institut „verejné moci“ je vnímán jako institut, qabrnujicí primou „moc státni" a dále „zbývajici verejnou moc“. Státni moci disponuje sám stát a zabezpečuje ji prostrednictvím svého

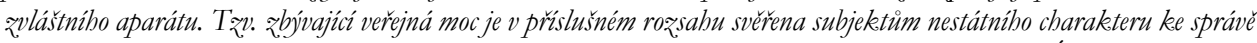
verejných záležitostí, je od státni moci v jistém smyslu odvoz̧ena a nemůže s ni být v rozporu". Nález Ústavního soudu ze dne 1. 12. 1998, sp. zn. I. ÚS 41/98.

76 Faktické úkony realizují orgány veřejné správy nejčastěji na základě zmocnění obsažených v právních předpisech náležejících do oblasti správního či trestního práva. Ojediněle jsou oprávnění k realizaci faktických úkonů upraveny i v rámci právních předpisů náležejících do jiných právních odvětví, např. občanského práva. Srov. např. \52 zákona č. 99/1963 Sb., občanského soudního řádu, ve znění pozdějších předpisů (dále jen ,občanský soudní řád“).

77 MATES, P. a M. STARÝ. Základy správního práva. Obecná část. 1. vyd. Praha: EUPRESS - Vysoká škola finanční a správní, 2009, s. 107. 
přesahuje, minimálně v tom smyslu, co je za výkon veřejné správy tradičně v rámci vědy správního práva považováno.

Mimo rámec výkonu veřejné správy se nachází zejména některé zajišt’ovací instituty, jež jsou využívány v rámci trestního řízení soudního, jež mají povahu opatření nezbytného pro zajištění řádného průběhu tohoto řízení, k jejichž realizaci jsou však oprávněny orgány veřejné správy (nejčastěji policie). Jedná se např́klad o zadržení osoby podezřelé ze spáchání trestného činu ${ }^{78}$ či vstup do obydlí, jiných prostor a na pozemek ${ }^{79}$ anebo odnětí věci ${ }^{80}$ či osobní prohlídku. ${ }^{81,82}$

Dle mého názoru tak z materiálního hlediska lze mezi faktické úkony zařadit i neformální činnosti právní povahy vykonávané ze strany orgánů veřejné správy (zpravidla policie) v rámci trestního řízení soudního, ${ }^{83}$ či sloužící k zajištění řádného průběhu jiného řízení (například civilního soudního řízeni ${ }^{84}$ nebo řízení vyšetřovací komise Poslanecké sněmovny Parlamentu České republiky) ${ }^{85}$, jež mají povahu bezprostředního opatření, proti kterému zákon nepřipouští v průběhu jeho realizace žádné opravné prostředky, a to i přesto, že příslušná řízení probíhají v oblasti pưsobnosti orgánů moci soudní či zákonodárné, tedy mimo výkon veřejné správy.

\section{Systematika faktických úkonů z hlediska správně-právní teorie}

Jak již bylo řečeno, neformální činnosti orgánů veřejné správy představují značně rozsáhlou a nesourodou matérii. Za účelem většího zpřehlednění je možno veškeré neformální projevy veřejné správy rozdělit do tří základních skupin (viz schéma č. 1). S tímto způsobem členění se lze běžně setkat v rámci odborné literatury. ${ }^{86}$

První skupinu tvoří tzv. exekuční úkony neboli úkony realizované orgány veřejné správy při výkonu jejich rozhodnutí. Správní exekuce představuje donucení ke splnění dobrovolně nesplněné právní povinnosti, uložené dřive, a to na základě rozhodnutí vydaného

78 Viz \ 75 a 76 zákona č. 141/1961 Sb., o trestním řízení soudním, ve znění pozdějších předpisů (dále jen „trestní ř́d“).

79 Viz $\int 83$ c trestního řádu.

80 Viz $\int 79$ trestního řádu.

81 Viz $\int 82$ odst. 3 a 4 trestního řádu.

82 Tyto úkony mají svůj zrcadlový odraz i v oblasti správního práva, konkrétně v zákoně o policii.

83 Například již zmíněné zadržení osoby podezřelé ze spáchání trestného činu nebo omezení osobní svobody, na základě trestním soudem vydaného př́kazu k zatčení dle $\int 75,76$ a \69 trestního řádu.

84 Viz např. předvedení osoby, která se bez omluvy nedostavila na předvolání dle $\int 52$ občanského soudního rádu.

85 Viz čl. 27 jednacího řádu vyšetřovací komise Poslanecké sněmovny Parlamentu České republiky, publikovaný jako př́loha č. 1 k zákonu č. 90/1995 Sb., o jednacím řádu Poslanecké sněmovny, ve znění pozdějších předpisů (dále jen ,zákon o jednacím řádu Poslanecké sněmovny“), dle kterého lze svědka, který se bez řádné omluvy nedostaví na předvolání předvést prostřednictvím policejního orgánu.

86 Viz např. HENDRYCH, D. a kol. Spráuni právo. Obecná cást. 9. vyd. Praha: C. H. Beck, 2016, s. 185-190. 
ve správním řízení prřislušným orgánem veřejné správy. ${ }^{87}$ Způsoby provádění exekucí upravují obecné právní předpisy procesní povahy. ${ }^{88}$ Nicméně mezi neformální projevy veřejné správy, jež mají pro její adresáty přímé právní důsledky, lze zařadit pouze ty exekuční úkony, které mají povahu bezprostředního fyzického donucení ke splnění dobrovolně nesplněné právní povinnosti neboli tzv. exekuci přímým vynucením. ${ }^{89}$

Nicméně v rámci nauky nepanuje shoda na tom, zda je možno ty exekuční úkony, které mají podobu fyzického donucení ke splnění dobrovolně nesplněné právní povinnosti, řadit mezi faktické úkony nebo zda exekuční úkony představují samostatnou skupinu správně-právních činností. Vzhledem k tomu, že bezprostřední zásahy mají na rozdíl od exekučních úkonů podobu reakce na neočekávané, náhle vzniklé nebezpečí nebo protiprávní jednání či stav, plně se ztotožňuji s názorem, který prezentuje exekuční úkony realizované prostřednictvím prrímého vynucení dobrovolně nesplněné právní povinnosti jako samostatnou skupinu neformálních projevů veřejné správy. ${ }^{90}$

Druhou skupinu představují tzv. faktické úkony, jež spočívají v oprávnění některých orgánů veřejné správy (nejčastěji veřejných sborů či orgánů pověřených na základě zákona výkonem správního dozoru) zasáhnout ${ }^{91}$ bezprostředně různým zpơsobem

87 Srov. SKULOVÁ, S. a kol. Správni právo procesní. 3. vyd. Plzeň: Aleš Čeněk, 2017, s. 85-88.

88 V oblasti výkonu veřejné správy jsou těmito předpisy správní řád a zákon č. 280/2009 Sb., daňový řád, ve znění pozdějších předpisů (dále jen „daňový řád“).

89 Konkrétně se jedná o správní exekuci na nepeněžitá plnění realizovanou prostřednictvím vyklizení nemovitosti, odebrání movité věci, osobní prohlídky či prohlídky bytu nebo jiných prostor nebo předvedení povinné osoby dle $\int 120$ až 128 správního řádu. Naproti tomu exekuce provedená prostřednictvím ukládání donucovacích pokut či náhradního výkonu postrádá výše zmíněné znaky neformálnosti a bezprostřednosti, ale zejména prímého fyzického donucení. To stejné je možno říci i o správní exekuci na peněžitá plnění, při níž se uplatní postup upravený daňovým řádem.

90 V rámci literatury se lze setkat s názorem, že exekuční úkony náleží do skupiny faktických úkonů, označované jako tzv. bezprostřední zásahy. Je ovšem otázkou, zda lze exekuční úkony mezi bezprostřední zásahy (jejichž hlavním znakem je, jak již bylo řečeno, reakce na náhle vzniklé nebezpečí nebo protiprávní jednání či stav) vủbec řadit. „V rámci nauky není jednota v tom, zda povabu bezprostredního zásabu má $i$ prímé vynuceni povinnosti v rámci správního rízení. Zatímco $V$. Sládeček a P. Prücha maji za to, že v širšm slova smyslu náleži exekučni úkony mezi bezprostredni zásaby, Z. Lukeš dovozuje, že jde o dva různé právni instituty a rozdil mezi nimi spatruje predevšim v tom, že exekuci predcházi formalizované správni řżení, které je naopak vyloučeno u bezprostredního zákroku. RovněžJ. Staša chápe exekucni úkony jako specifickou kategorii správních úkonü, která nespadá mezi bezprostredni zásaby. Za pravdu je třeba dát spíse drubé skupině autori. Hlavni dưvod netkvi ani tak v tom, zda se tu jedná o výsledek formalizovanébo ř́zeni ci nikoliv, byt' jde o neprehlédnutelný rozdil, ale predevšm ve smyslu toho keterého institutu: bezprostredni zásah má totiž chránit préd aktuálním nebezpečim, které v prípadè exekučního úkonu nelze identifikovat". MATES, P., J. ŠKODA a F. VAVERA. Verejné sbory. 1. vyd. Praha: Wolters Kluwer ČR, 2011, s. 14-15. Taktéž německá literatura řadí exekuční úkony realizované v podobě výkonu správního rozhodnutí do zvláštní kategorie správně-právních činností nazývaných jako tzv. správní donucení. Viz WITTERN, A. Grundriß des Verwaltungsrechts. 18 vyd. Köln: W. Kohlhammer, 1994, s. 166-173.

91 „Definici zásabu zákon neobsabuje, zásah vymezuje velmi obecně a šroce. Samotný pojem ,zásab“ ve smyslu $\int 82$ s. r.s. (soudni rád správní) pak neni definován žádným ustanovením s. r. s. ani jiného právního predpisu. Presná definice totiž neni ani možná, protože pod pojem zásah spadá velké množstvi faktických činnosti správních orgámü, ke kterým jsou rưznými zákony oprávněny“. Rozsudek Nejvyššího správního soudu ze dne 30. 4. 2008, č. j. 4 Aps 5/2007-53. 
do právních poměrů adresátů veřejné správy, jestliže je to při výkonu správního dozoru nezbytné $\mathrm{k}$ uvedení zjištěného stavu do souladu s právními normami nebo $\mathrm{k}$ ochraně bezpečnosti osob a majetku, prrípadně ochraně veřejného pořádku anebo bezpečnosti a plynulosti silničního provozu (faktické pokyny) nebo k ochraně některých významných zákonem chráněných zájmů, zpravidla (ovšem ne vždy) za použití síly (bezprostřední zásahy) anebo k zajištění řádného průběhu formalizovaného řízení (zajišt'ovací úkony). ${ }^{92}$ J. Staša dále rozděluje faktické úkony na ty, jež mají povahu fyzického donucení (v tomto př́padě se bude zpravidla jednat o bezprostřední zásahy) ${ }^{93}$ a na ty, jež povahu fyzického donucení nemají (nejčastěji faktické pokyny). ${ }^{94,95}$ Nicméně zde je třeba zdůraznit, že terminologie užívaná v souvislosti s označením neformálních projevů veřejné správy, s níž se lze v odborné literatuře běžně setkat, stejně jako míra diferenciace předmětné matérie, se v př́ípadě jednotlivých autorů značně liší. Tyto terminologické a diferenciační rozdíly tak následně způsobují interpretační potíže a to zejména při bližším členění neformálních činností orgánů veřejné správy (nejčastěji souhrnně označované jako faktické úkony či faktické zásahy), ${ }^{96}$ stejně jakož i při přisuzování charakteristických vlastností jejich jednotlivým formám. Např. V. Sládeček hovoří v souvislosti s neformální činností orgánů veřejné správy pouze o „bezprostředních zásazích“, přičemž jiné skupiny faktických úkonů nevymezuje a pod zmiňovaný pojem řadí i neformální správně-právní úkony nižšîi intenzity (např̀. prokázání totožnosti, př́kaz nevstupovat a nezdržovat se na určitých místech atd.). ${ }^{97}$ Přičemž ze strany jiných autorů bývá pojmem „bezprostřední zásahy“ zpravidla označována podskupina faktických úkonů, charakteristická zejména svojí intenzitou zásahu do práv a svobod osob. ${ }^{98}$ Tento stav podporuje mnou zastávaný názor, že podrobné členění neformálních projevů veřejné správy má význam právě z hlediska extrakce jejich specifických vlastností a znaků.

92 Dle rozsudku Nejvyššího správního soudu ze dne 30. 4. 2008, č. j. 4 Aps 5/2007-53. „Tyto úkony pro svoji neodkladnost nejsou uskutečnovány jïnak obvyklým procesním postupem, respektujicim všechna procesni pravidla správníbo rízení, zakončeným vydáním správního roz̧hodnutí. Dưvodem takových autoritativních úkonu je typicky neodkladná potreba ochrany života, zdravi, majetku a veřejnébo poŕádku. Jde tedy o úkony neformální, pro keteré mohou a nemusí být stanovena pravidla, naprr. faktické pokyny (typicky v dopravé), bezprostrédni zásaby (prí obrožení, prí demonstraci, príkazy ke zjednáni nápravy), zajištovaci úkony atd., tedy obecnè úkony, které nejsou činèny formou rozhodnutí, ale presto jsou závazné pro osoby vůci nimž smèrují, a ty jsou povinny na jejich základě něco konat nèjaké cünnosti se qdržet nebo nèjaké jednáni strpèt, a to na základè jak pisemnébo, tak i faktického (üstního či jinak vyjádreného) pokynu či príkazu."

93 Typickým prŕkladem je použití donucovacích prostředků ze strany policisty dle $\int 51$ a násl. zákona o policii.

94 Zde se může jednat např́klad o zákaz vstupu na policistou určené místo dle $\int 43$ odst. 1 písm. a) zákona o policii.

95 Srov. STAŠA, J. Úvod do českého správního práva. 4. vyd. Praha: Policejní akademie České republiky, 2003, s. 85 .

96 „Faktické zásaby - v literatuře též bezprívlastku nebo jako soubor podskupin (faktické pokyny, bezprostredni zásaby či zákroky a ostatni donucovaci úkony)“. POMAHAČ, R. et. al. Verejná správa za rozcestím (právni reflexe). 1 . vyd. Praha: Univerzita Karlova v Praze, Právnická fakulta, 2013, s. 36.

97 Viz SLÁDEČEK, V. Obecné správní právo. 3. vyd. Praha: Wolters Kluwer ČR, 2013, s. 189-190.

98 Viz např. HENDRYCH, D. a kol. Spráuni právo. Obecná cást. 9. vyd. Praha: C. H. Beck, 2016, s. 189-190. 
Třetí skupinu neformálních projevů veřejné správy tvoří tzv. příbuzné úkony, ${ }^{99}$ označované též jako úkony neregulativní povahy. ${ }^{100} \mathrm{Na}$ základě aplikace správně-právních norem dochází v některých př́padech $\mathrm{k}$ realizaci činností, jež mají povahu zásahu do právních poměrů fyzických či právnických osob, přičemž tyto činnosti nebývají z pohledu nauky zpravidla řazeny mezi faktické úkony. Jedná se o instituty podobné faktickým úkonům, které ovšem pojmově nemusí vždy představovat správně-právní činnosti (např̀. nedobrovolné poskytování zdravotnických služeb či uplatnění omezovacích prostředků s tím spojených). ${ }^{101,102}$ Tyto úkony se vyznačují ještě větší mírou neformálnosti, než jak je tomu $\mathrm{v}$ př́padě faktických úkonů. Tomu odpovídá skutečnost, že v př́padě, kdy se jedná o oprávnění $\mathrm{k}$ zásahu do ústavně zaručených práv a svobod osob za použití síly, nejsou tyto činnosti zákonem tak detailně upraveny, jako je tomu v prrípadě ryze správně-právních činností obdobného charakteru (například použití donucovacích prostředků ze strany příslušníků bezpečnostních sborů). To je dáno především povahou těchto úkonů, nebot' se v jejich př́ípadě, jak již bylo řečeno, nejedná o typické správní úkony. ${ }^{103}$

Dále je v této souvislosti možno zmínit oprávnění řidiče veřejné linkové dopravy nebo jiné osoby pověřené dopravcem (tzv. revizora) udělovat cestujícím pokyny a prŕkazy k zajištění jejich bezpečnosti, bezpečnosti a plynulosti dopravy a bezpečnosti ostatních cestujících, dále vyloučit za zákonem stanovených podmínek cestujícího z dopravy a požadovat po cestujícím, který se neprokázal platným jízdním dokladem, předložení osobního dokladu (dokladu totožnosti). ${ }^{104,105} \mathrm{~V}$ těchto prípadech fyzické osoby, jež však

99 Viz HENDRYCH, D. a kol. Správní právo. Obecná cást. 9. vyd. Praha: C. H. Beck, 2016, s. 189.

100 Viz STAŠA, J. Úvod do českého správního práva. 4. vyd. Praha: Policejní akademie České republiky, 2003, s. 88.

101 Viz $\ 38$ odst. 1 písm. b) a c) a \39 zákona č. 372/2011 Sb., o zdravotních službách a podmínkách jejich poskytování, ve znění pozdějších předpisů (dále jen „zákon o zdravotních službách a podmínkách jejich poskytováni").

102 Srov. HENDRYCH, D. a kol. Spráuní právo. Obecná cást. 9. vyd. Praha: C. H. Beck, 2016, s. 189-190.

103 Viz např́klad již zmíněné omezovací prostředky uplatňované v rámci nedobrovolného poskytování zdravotnických služeb dle $\int 39$ zákona o zdravotních službách a podmínkách jejich poskytování, které se svojí povahou podobají donucovacím prostředkům realizovaným ze strany př́slušníků bezpečnostních sborů, nicméně forma jejich zákonné úpravy je oproti donucovacím prostředkům méně podrobná a stejně tak např́klad požadavky na přezkum oprávněnosti použití těchto prostředků v př́padě, že v souvislosti s jejich realizací došlo ke zranění osoby (pacienta) jsou upraveny rozdílně. Použití omezovacích prostředků se pouze zaznamenává do zdravotnické dokumentace pacienta a do centrální evidence použití omezovacích prostředků. Naproti tomu po použití donucovacích prostředků je zasahující příslušník bezpečnostního sboru povinen učinit neodkladné úkony nebo jiná opatření, aby mohla být řádně objasněna oprávněnost jeho použití, dále je povinen takový zákrok bezodkladně hlásit svému nadřízenému, který na základě jím sepsaného úředního záznamu, $\mathrm{v}$ němž je povinen uvést důvod, průběh a výsledek zásahu vyhodnotí jeho oprávněnost. V př́padě, že v souvislosti s použitím donucovacích prostředků došlo ke zranění osoby, je vedoucí př́slušného útvaru povinen o této skutečnosti vyrozumět bez zbytečného odkladu státního zástupce. Srov. např. $\int 57$ zákona o policii.

104 Viz \18a odst. 1 zákona č. 111/1994 Sb., o silniční dopravě, ve znění pozdějších předpisů.

105 Dle $\int 9$ dnes již zrušeného zákona č. 51/1964 Sb., o drahách, ve znění pozdějších předpisů byli pracovníci drážního podniku ve stejnokroji nebo se služebním odznakem oprávnění v obvodu dráhy zjišstovat totožnost osob, které narušovaly nebo ohrožovaly drážní provoz, majetek, bezpečnost života nebo zdraví osob nebo se neoprávněně zdržovaly v obvodu dráhy a bylo-li to nezbytné též takovou osobu zadržet a odevzdat ji bez zbytečných průtahů orgánům Veřejné bezpečnosti nebo v obvodu celostátních drah železničním ozbrojeným orgánům. 
na rozdíl například od veřejných stráží nemají postavení správního orgánu, za použití norem správního práva vynucují oprávněné nároky svých zaměstnavatelů, vyplývající ze soukromoprávních smluvních vztahů.

Schéma č. 1: Členění neformálních projevů veřejné správy z hlediska správně-právní teorie

EXEKUČNÍ ÚKONY FAKTICKÉ ÚKONY PŘÍBUZNÉ ÚKONY

Zdroj: Vypracováno autorem na základě závěrů představených v rámci odborné literatury. ${ }^{106}$

Současná věda správního práva rozděluje faktické úkony (dle jejich účelu a způsobu realizace) do tří základních skupin. Např́klad J. Staša faktické úkony (jím označované jako faktické zásahy) člení „v závislosti na charakteru a kontextu správního pưsobení na:

a) faktické zásaby, které znači prostý príkaz nebo zákaz určitého chováni - faktické pokyny,

b) faktické zásahy spočivajici v efektivním donucování, poprǐpadè v jeho prǐmé hrozbè, jejichž smyslem je odvrátit aktuálně brozicí nebezpeč - bezprostřední zásahy,

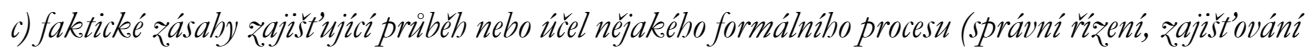
prì výkonu správníbo dozoru) - zajišt'ovací úkony". ${ }^{107}$

S totožným či obdobným dělením faktických úkonů se lze setkat v rámci převážné většiny odborných publikací věnovaných obecné části správního práva. Pro názornost je možno toto členění faktických úkonů na jednotlivé skupiny graficky znázornit následujícím způsobem (viz schéma č. 2).

Schéma č. 2: Členění faktických úkonů dle účelu a způsobu realizace

\begin{tabular}{|l|l|}
\hline \multirow{2}{*}{ FAKTICKÉ ÚKONY } & Faktické pokyny \\
\hline & Bezprostřední zásahy \\
\hline Zajištovací úkony \\
\hline
\end{tabular}

Zdroj: Vypracováno autorem na základě závěrů představených v rámci odborné literatury. ${ }^{108}$

S podrobnějším členěním jednotlivých skupin faktických úkonů se lze v rámci odborné literatury setkat spíše sporadicky, nicméně někteří autoři se ve svých dílech touto problematikou zabývají. ${ }^{109}$ Z literatury (v kombinaci s analýzou př́slušné právní úpravy) lze dovodit následující podrobnější způsob členění faktických úkonů koncipovaný s ohledem na způsob jejich realizace či předmět jejich působení (viz schéma č. 3). Zde je třeba poznamenat, že podobným způsobem, tedy způsobem, který lze graficky znázornit

106 Viz HENDRYCH, D. a kol. Správní právo. Obecná ćást. 9. vyd. Praha: C. H. Beck, 2016, s. 185-190.

107 STAŠA, J. Úvod do českého správního práva. 4. vyd. Praha: Policejní akademie České republiky, 2003, s. 85. 108 Viz Ibid., s. 85.

109 Viz např. HENDRYCH, D. a kol. Správní právo. Obecná cást. 9. vyd. Praha: C. H. Beck, 2016, s. 185-190; MASAŘÍK, J. a V. KRICNER. Správní právo. Obecná ćást. 7. vyd. Praha: Armex publishing, 2015, s. 79-80; PIKOLA, P., J. BORSKÁ a R. KORCOVÁ. Správní právo prakticky. 1. vyd. Praha: Česká zemědělská univerzita v Praze, Provozně-ekonomická fakulta, 2014, s. 66-67. 
prostřednictvím dvouúrovňového schématu, člení faktické úkony například i rakouská správně-právní nauka. ${ }^{110}$

Schéma č. 3: Členění jednotlivých skupin faktických úkonů z hlediska způsobu realizace a předmětu působení

\begin{tabular}{|l|l|}
\hline \multirow{2}{*}{ FAKTICKÉ POKYNY } & Vykonávané ústně \\
\hline \multirow{2}{*}{$\begin{array}{l}\text { BEZPROSTŘEDNÍ } \\
\text { ZÁSAHY }\end{array}$} & Vykonávané písemně \\
\hline & Vykonávané prostřednictvím gest \\
\hline \multirow{2}{*}{ Donuné prostřednictvím technického zařízení } \\
\hline ZAJIŠŤOVACí prostředky \\
\hline
\end{tabular}

Zdroj: Vypracováno autorem na základě závěrů představených v rámci odborné literatury. ${ }^{111}$

\subsection{Faktické pokyny}

Jako faktické pokyny jsou označovány neformální správně-právní úkony, realizované prŕislušnými úředními osobami na základě konkrétního zákonného zmocnění, zpravidla „v terénu“ mimo prostory vykonavatelů veřejné správy, jež spočívají ve vyslovení:

a) zákazu nebo

b) př́ikazu určitého jednání, jež je pro adresáty veřejné správy právně závazný a osoby, vưči nimž byl tento úkon učiněn, jsou povinny se mu podřídit.

110 Rakouská nauka člení faktické úkony v první úrovni na:

1) př́kazy a 2) donucení.

Ve druhé úrovni rozděluje př́kazy na:

a) bezprostřední pokyny,

b) zprostředkované akty a c) trestně-správní pokyny.

Donucovací úkony ve druhé úrovni dělí na:

a) fyzické donucení,

b) právní zásahy s implicitním pořádkovým charakterem a

c) jiné právní zásahy.

Srov. KOJA, F. a W. ANTONIOLLI. Allgemeines Verwaltungsrecht. Lehr-und Handbuch für Studium und Praxis. 2 vyd. Wien: Manzsche Verlags- und Universitätsbuchhandlung, 1986, s. 489.

111 Viz HENDRYCH, D. a kol. Spránni právo. Obecná cást. 9. vyd. Praha: C. H. Beck, 2016, s. 185-190. 
Faktické úkony mohou být realizovány prostřednictvím:

a) ústních pokynư ${ }^{112}$,

b) gest $^{113}$,

c) technického zařízení. ${ }^{114,115}$

Přesto, že se jedná o neformální projevy veřejné správy, jež zpravidla nejsou v podrobnostech legislativně přesněji upraveny, ${ }^{116} \mathrm{v}$ některých př́padech zákon jejich formu ${ }^{117}$ či obsah ${ }^{118}$ více či méně konkrétně výslovně předepisuje. ${ }^{119}$ Oproti ostatním formám faktických úkonů nepředstavují faktické pokyny zpravidla nijak závažné zásahy do právních poměrů adresátů veřejné správy. Nicméně na druhou stranu je třeba zdůraznit, že konkrétní míra intenzity je v rámci jednotlivých faktických pokynů značně odlišná. ${ }^{120}$

Z hlediska jejich účelu je možno faktické pokyny rozdělit do dvou skupin:

a) První skupinu tvoří pokyny, které stojí samostatně a jejichž cílem je pouze naplnění příslušného zákazu či př́kazu bez vazby na jiný úkon př́slušného orgánu. ${ }^{121}$

b) Druhou skupinu představují př́kazy a zákazy, jež jsou součástí jiného zpravidla taktéž neformálního projevu veřejné správy (naprríklad bezprostředního zásahu, zajišt’ovacího úkonu či jsou prvním úkonem $\mathrm{v}$ zahájeném správním řízenî). $\mathrm{V}$ tomto

112 Např. př́kaz policisty směřující $\mathrm{k}$ zákazu vstupu na určené místo či k setrvání na tomto místě dle $\int 43$ odst. 1 zákona o policii.

113 Např. pokyny policisty udílené při řízení provozu na pozemních komunikacích dle $\int 75$ odst. 1 a 4 zákona č. 361/2000 Sb., o provozu na pozemních komunikacích a o změnách některých zákonů, ve znění pozdějších předpisů (dále jen ,zákon o provozu na pozemních komunikacích“).

114 Např. zastavení vozidla oprávněnou úřední osobou z jedoucího služebního vozidla prostřednictvím rozsvícení nápisu „STOP“ ze směru jízdy zastavovaného vozidla, a to zepředu i zezadu dle $\int 79$ odst. 2 zákona o provozu na pozemních komunikacích.

115 Srov. HENDRYCH, D. a kol. Správni právo. Obecná cást. 9. vyd. Praha: C. H. Beck, 2016, s. 186.

116 Viz např. výzva inspektora Státního úřadu inspekce práce směřující vůči kontrolované osobě, aby se tato $\mathrm{v}$ určité lhưtě dostavila na pracoviště úřadu nebo inspektorátu učiněná dle $\int 9$ odst. 1 zákona č. 251/2005 Sb., o inspekci práce, ve znění pozdějších předpisů.

117 Např. již zmíněné pokyny policisty udílené při řízení provozu na pozemních komunikacích dle $\int 75$ odst. 1 a 4 zákona o provozu na pozemních komunikacích.

118 Např. výzva s výstrahou učiněná ze strany policisty vůči osobě, proti které zakročuje, že v případě, kdy osoba neupustí od svého protiprávního jednání, bude vůči ní použito donucovacích prostředků nebo zbraně. Viz \53 odst. 2 a \56 odst. 3 zákona o policii. Jako obligatorní součást této výzvy zákon předepisuje užití slov „, Jménem zákona!“ Viz \10 odst. 5 tohoto zákona.

119 Srov. POMAHAČ, R. et. al. Verejná správa za roz̧cestím (právní reflexe). 1. vyd. Praha: Univerzita Karlova v Praze, Právnická fakulta, 2013, s. 46.

120 Prostřednictvím faktických pokynů je legislativně řešena celá řada různých situací. Z toho vyplývá i rozdílná intenzita zásahu do práv a svobod osob v jednotlivých př́padech. V tomto smyslu je možno zmínit na jedné straně např́klad výše zmíněné pokyny policisty k zastavení vozidla dle \79 odst. 2 zákona o provozu na pozemních komunikacích a na straně druhé vykázání ze společného obydlí dle $\int 44$ až 47 zákona o policii.

121 Např. pokyny policisty udílené při řízení provozu na pozemních komunikacích uskutečňované dle $\int 75$ odst. 1 a 4 zákona o provozu na pozemních komunikacích. 
prípadě se zpravidla jedná o poučení o právech a povinnostech osoby, proti níž zásah směřuje nebo o poučení o právech a povinnostech osoby omezené ze strany orgánů veřejné moci na svobodě. ${ }^{122}$

Na základě analýzy pozitivní právní úpravy, jakož i s ohledem na diferenciaci administrativně-právního působení $\mathrm{v}$ jednotlivých oblastech veřejné správy je možno faktické pokyny rozdělit na:

a) Faktické pokyny vydávané v návaznosti na výkon správního dozoru, ${ }^{123}$

b) faktické pokyny realizované $\mathrm{v}$ souvislosti s výkonem policejně-bezpečnostních činností, při zajišt’ování veřejného pořádku a ochraně bezpečnosti osob a majetku ${ }^{124} \mathrm{a}$

c) faktické pokyny uskutečňované $\mathrm{v}$ rámci dohledu nad bezpečností a plynulostí silničního provozu. ${ }^{125}$

\subsection{Bezprostřední zásahy}

Bezprostřední zásahy tvoří skupinu správně-právních úkonů, jejichž společným znakem je, že jsou realizovány v př́padě, kdy není možno uplatnit mírnější postup a jou ze strany prŕslušných úředních osob uskutečňovány $\mathrm{v}$ podobě bezprostřední reakce na aktuálně hrozící nebezpečí nebo trvající protiprávní jednání či stav, přičemž jejich realizace je vždy spojena s fyzickým zásahem do základních práv a svobod, který je v danou chvíli nezbytný $\mathrm{k}$ ochraně významných zákonem chráněných zájmů. ${ }^{126}$

Bezprostřední zásahy slouži $\mathrm{k}$ zachování, př́padně obnově bezporuchového chodu společnosti v souladu s právem. Jedná se o primární ochranu zájmů státu, jakož i práv a oprávněných zájmů jednotlivých osob prostřednictvím aplikace práva tj. bezprostřední

122 Např. dle $\int 13$ zákona o policii je policista povinen před provedením úkonu poučit osobu dotčenou úkonem o právních důvodech provedení úkonu, a jde-li o úkon spojený se zásahem do práv nebo svobod osoby, také o jejích právech a povinnostech. Toto poučení má zpravidla (co se týká stanovení povinností osoby, vůči níž úkon směřuje) povahu jednostranného autoritativního stanovení př́kazů a zákazů. Dále je v této souvislosti možno zmínit výzvu policisty aby osoba upustila od svého protiprávního jednání, s výstrahou, že jinak bude vůči ní použito donucovacích prostředků nebo zbraně. Viz \53 odst. 2 a $\int 56$ odst. 3 zákona o policii.

123 Např. oprávnění požadovat v souvislosti s kontrolou poskytnutí údajů, dokumentů a věcí vztahujících se k předmětu kontroly nebo k činnosti kontrolované osoby a vyžadovat od kontrolované osoby a povinné osoby další součinnost potřebnou k výkonu kontroly. Viz \8 písm. c) a f) zákona č. 255/2012 Sb., o kontrole, ve znění pozdějších předpisů (dále jen ,kontrolní rád“).

124 Např. již zmíněná výzva s výstrahou učiněná ze strany policisty vưči osobě, proti které zakročuje, že v př́ipadě, kdy osoba neupustí od svého protiprávního jednání, bude vůči ní použito donucovacích prostř̌edků nebo zbraně. Viz \53 odst. 2 a \56 odst. 3 zákona o policii.

125 Jedná se např́klad o již zmíněné pokyny policisty udílené při řízení provozu na pozemních komunikacích uskutečňované dle $\int 75$ odst. 1 a 4 zákona o provozu na pozemních komunikacích.

126 Právní teorie definuje bezprostřední zásahy zpravidla jako úkony ,provádèné na základè speciálního zákonného żmocnèni za stavu, kdy je právem chránèný zájem bezprostředně obrožen“. ŠKODA, J., F. VAVERA a R. ŠMERDA. Zákon o policii s komentárem. 2. vyd. Plzeň: Aleš Čeněk, 2013, s. 167. 
ochranu, která se v řadě směrů zcela zásadně liší od ochrany sekundární, jež je výsledkem formalizovaného řízení (správního či soudního). ${ }^{127}$

Realizace bezprostředních zásahů představuje v rámci výkonu veřejné správy ultima ratio, tedy nejzazší možnost, spočívající v aplikaci těch nejintenzivnějších prostředků státního donucení, které jsou orgány veřejné správy oprávněny vưči adresátům svého působení uplatnit v situaci, kdy mírnější prostředky nejsou či by zjevně nebyly k dosažení stanoveného cíle dostačující.

Bezprostřední zásahy je možno z hlediska povahy jejich působení rozdělit na:

a) bezprostřední opatření,

b) bezprostřední donucení,

c) bezprostřední omezení.

Tento zpơsob členění bezprostředních zásahů je možno graficky znázornit následujícím způsobem (viz schéma č. 4).

\subsubsection{Bezprostredni opatreni}

Bezprostřední opatření mohou být namířena jak vưči osobám, tak (zpravidla častěji) vůči věcem. Jejich funkce spočívá v působení na:

a) osoby, ${ }^{128}$

b) movité ${ }^{129}$ nebo

c) nemovité věci. ${ }^{130}$

s cílem zajištění žádoucího právního stavu či zabránění protiprávnímu jednání či stavu.

Bezprostřední opatření $v$ případě, že jeho objektem je fyzická osoba, má zpravidla podobu zásahu do osobní integrity, př́ípadně soukromí, zásahem dotčené osoby. Nicméně realizace bezprostředního opatření není, na rozdíl od bezprostředního donucení, zpravidla spojena s fyzickým donucením a s tím souvisejícím rizikem zranění či usmrcení osoby, proti níž zásah směřuje. ${ }^{131}$

127 Prostř̌ednictvím aplikace trestně-právních, případně správně-právních norem trestní povahy je poskytována sekundární ochrana zákonem chráněným zájmům (například životu, zdraví, majetku a svobodě osob). Trest za porušení těchto norem představuje výsledek aplikace práva, uskutečněné prostřednictvím realizace formalizovaného procesu příslušného orgánu (např. soudu). Nicméně trest uložený pachateli chrání tato práva a svobody až následně (sekundárně), tedy v momentě, kdy již nebezpečí bezprostř̌edně nehrozí (např. jedním z účelů nepodmíněného trestu odnětí svobody je zabránit pachateli v páchání další trestné činnosti a chránit tak ostatní členy společnosti). Naproti tomu bezprostřední zásahy (jež nejsou trestem, ale opatřením) poskytují těmto právưm ochranu bezprostředně. Například použití donucovacích prostředků proti osobě, která fyzicky napadá jinou osobu, za účelem ochrany napadené osoby, představuje primární právní ochranu.

128 Viz např. oprávnění policisty provést prohlídku osoby před jejím umístěním do policejní cely dle $\int 29$ zákona o policii.

129 Viz např. oprávnění policisty zničit věc dle $\int 37$ odst. 2 zákona o policii.

130 Viz např. oprávnění policisty ke vstupu do obydlí, jiného prostoru nebo na pozemek dle $\int 40$ zákona o policii.

131 Např. prohlídka osoby a odebrání věcí před umístěním do policejní cely dle \29 zákona o policii. 


\subsubsection{Bezprostredni donucení}

Bezprostřední donucení spočívá ve fyzickém zásahu do práv a svobod osob za účelem ochrany významných zákonem chráněných zájmů v prrípadě, kdy mírnější právní prostředky nejsou či by zjevně nebyly dostatečně účinné. ${ }^{132}$ Oprávněním k realizaci bezprostředního donucení disponují pouze příslušníci ozbrojených bezpečnostních sborů a obecní policie. Bezprostřední donucení zahrnuje:

a) použití donucovacích prostředků nebo

b) použití zbraně.

V prípadě bezprostředního donucení má zcela zásadní význam uplatnění zásady přiměřenosti. Jak v rámci nauky, tak i z hlediska judikatury se lze setkat s dvěma odlišnými názory na otázku přiměřenosti v př́padě realizace prostředků bezprostředního donucení. Většina autorů zastává názor, že v souvislosti se zásahem, při němž dochází ze strany orgánu veřejné správy k vynucení splnění právní povinnosti za použití fyzické síly, nesmí osobám, vůči nimž zásah směřuje vzniknout větší škoda, než jaká vznikla či hrozila v důsledku nebezpečí, které bylo prostřednictvím realizace zásahu odvráceno. ${ }^{133}$ Nicméně se lze setkat i s názorem, že obdobně jako v prŕpadě obecného institutu nutné obrany, tak i v případě uplatnění prostředků státně-mocenského donucení zákon nenařizuje př́ísnou proporcionalitu, ale umožňuje způsobit osobě i nepřiměřenou újmu, přičemž hranici staví o něco výše, a to na úroveň zřejmé, tedy zjevné, očividné nepřiměřenosti. ${ }^{134}$

Judikatura Ústavního soudu, ve shodě s judikaturou Evropského soudu pro lidská práva (dále jen „ESLP“), uplatňuje při hodnocení prriměřenosti zásahů, při nichž bylo ze strany orgánů veřejné správy užito fyzické síly, standard striktní nezbytnosti. ${ }^{135,136}$ Účelem aplikace standardu striktní nezbytnosti je zakotvení př́sné proporcionality v př́padě použití síly ze strany orgánů veřejné správy. ${ }^{137}$

Standard striktní nezbytnosti, skrze který Ústavní soud a ESLP posuzují priměřenost postupů orgánů veřejné správy při realizaci zásahů spojených s bezprostředním donucením, však zcela neodpovídá pozitivnímu vyjádření zásady přiměřenosti upravené v rámci jednotlivých právních předpisů ve vztahu k použití donucovacích prostředků. Tyto předpisy

132 Viz např. oprávnění k použití donucovacích prostředků a zbraně dle $\int 51$ až 59 zákona o policii.

133 Viz např. ŠKODA, J., F. VAVERA a R. ŠMERDA. Zákon o policii s komentárem. 2. vyd. Plzeň: Aleš Čeněk, 2009, s. 208.

134 Viz VANGELI, B. Zákon o Policii České republiky. Komentár. 2. vyd. Praha: C. H. Beck, 2014, 483 s.

135 „Standard striktni nezbytnosti, který je vyšši než samotná nezbytnost, dokládá, že stupeñ použiti síly nesmi být v žádném prípadě vyšší, než̃jaký postačuje k dosaženi sledovaného účlu“. Nález Ústavního soudu ze dne 17. 10. 2017, sp. zn. II. ÚS 1398/17.

136 „Jakékoliv donucovaci prostredky je nutno použivat pouze v míre nezbytně nutnépro dosažení legitimního účelu sledovanébo zákerokem“. Nález Ústavního soudu ze dne 27. 10. 2015, sp. zn. I. ÚS 860/15.

137 Viz např. Rozsudek Evropského soudu pro lidská práva ze dne 28. 9. 2015, Bouyid proti Belgii, sp. zn. $23380 / 09$. 
zásadu přiměřenosti, v souvislosti s použitím donucovacích prostředků, definují jako povinnost oprávněné úřední osoby, nezpůsobit osobě, proti níž zákrok směřuje, újmu zřejmě nepriměřenou povaze a nebezpečnosti jejího protiprávního jednání, ${ }^{138}$ z čehož vyplývá, že zákon umožňuje oprávněným úředním osobám způsobit osobě, proti níž zakročují, i nepřiměřenou újmu ve vztahu $\mathrm{k}$ povaze a nebezpečnosti jejîho protiprávního jednání, které prostřednictvím zásahu eliminuji. ${ }^{139}$ Zvlášt' markantní je rozdíl mezi pozitivním vyjádřením úrovně přiměřenosti a standardem striktní nezbytnosti v případě oprávnění použít zbraň ze strany orgánu veřejné správy v nutné obraně, ${ }^{140}$ nebot’ zde se prriměřenost řídí obecnými podmínkami nutné obrany vyjádřenými v \29 trestního zákoníku, redukovanými pouze požadavkem co nejvíce šetřit život osoby, proti níž zákrok směřuje. ${ }^{141,142}$

Co se týká pozitivního vyjádření standardu striktní nezbytnosti, tomu v podstatě odpovídají obecná ustanovení o přiměřenosti postupu příslušníků jednotlivých bezpečnostních sborů. ${ }^{143}$ Nicméně jak již bylo řečeno, tato obecná ustanovení o přiměřenosti jsou ve vztahu k oprávnění použít donucovací prostředky významným způsobem korigována. $\mathrm{V}$ př́padě uplatnění standardu striktní nezbytnosti v souvislosti s použitím donucovacích prostředků tak lze hovořit o zúžení rozsahu pozitivní právní úpravy prostřednictvím judikatury.

Současné právní úpravy (na rozdíl od některých úprav předchozích) již donucovací prostředky nikterak nerozlišuji.. ${ }^{144}$ Přesto, že jednotlivé zákony bližší specifikaci ani dělení donucovacích prostředků neuvádějí, ${ }^{145}$ tak vzhledem k povaze jednotlivých donucovacích

138 Srov. \53 odst. 5 zákona o policii, \17 odst. 3 zákona o vězeňské a justiční stráži, \44 odst. 5 zákona č. 17/2012 Sb., o Celní správě České republiky, ve znění pozdějších předpisů, \18 odst. 5 zákona ČNR č. 553/1991 Sb., o obecní policii, ve znění pozdějších předpisů (dále jen ,zákon o obecní policii“).

139 „Zákon policistovi ukládá dbát, aby nezpuisobil osobè újmu žrejmě neprimérenou povaze a nebezpečnosti jejího protiprávního jednání. Zákon tedy obdobně jako u obecnébo institutu nutné obrany nenařizuje prísnou proporcionalitu. Umožnuje zpuisobit osobě donucovacím prostredkem újmu nepriměrenou, hranici stavi o něco výše až na úroveñ žrejmé, tedy zjjevné, očividné neprimèrenosti. Tento prìstup vychází jednak z védomi objektivni složitosti těchto situací, která zpuisobuje praktickou nenaplnitelnost požadavku prǐsné proporcionality, a jednak zpovaby efektivního zákroku (obrany), kdy empirická

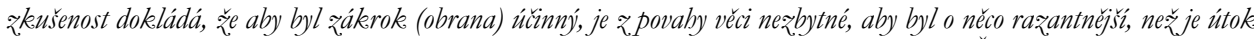
č jiné nebezpečné jednání, proti němu气̌ je zakročováno". Rozsudek Nejvyššího soudu ČR ze dne 5. 10. 2016, sp. zn. 30 Cdo 5661/2015.

140 Viz např. \56 odst. 1 písm. a) zákona o policii či \ 20 odst. 1 písm. a) zákona o obecní policii.

141 Srov. např. \56 odst. 4 zákona o policii.

$142 \mathrm{Na}$ rozdíl od jiných právních předpisů upravujících oprávnění použít zbraň, zákon o obecní policii stanoví mimo podmínky, co nejvíce šetřit život osoby, proti níž zákrok směřuje, též požadavek co nejvíce šetřit zdraví této osoby.

143 Viz např. \ 11 písm. c) zákona o policii či \ 6 odst. 2 zákona o vězeňské a justiční stráži.

144 Srov. \39a odst. 2 starého zákona o policii, který rozlišoval donucovací prostředky na běžné a speciální.

145 „Zákon o policii donucovaci prostředek nedefinuje pojmově, ale pomoci enumerace prostředkù, které zahrnuje do množiny donucovacich prostredku. Poradi donucovacich prostredkü podle \52 zákona o policii nezakládá jejich bierarchii. Jde o poubý výcet možných prostredkư vyuřitelných prì zákroku k ochranè chránèných zájmư . ŠKODA, J., F. VAVERA a R. ŠMERDA. Zákon o policii s komentárem. 2. vyd. Plzeň: Aleš Čeněk, 2009, s. 199 a 208. 
prostředků a jejich předpokládanému účinku na lidské tělo by bylo možno donucovací prostředky rozdělit na:

a) mírnější a

b) důraznější.

Vodítko pro takové rozdělení donucovacích prostředků tvoří obsahy omezujících ustanovení zakotvené $\mathrm{v}$ rámci jednotlivých právních předpisů, jež upravují jejich použití. ${ }^{146}$ Z obsahu těchto ustanovení lze dovodit, že za mírnější donucovací prostředky lze považovat hmaty, chvaty, poutací prostředky a prostředek k zamezení prostorové orientace. $^{147,148}$

Nicméně při řazení konkrétních donucovacích prostředků do skupiny mírnějších či důraznějších donucovacích prostředků je třeba, mimo pozitivní zákonné úpravy, vycházející z jejich předpokládaného působení na lidské tělo, zohlednit též způsob a místo jejich použití. To se týká především poutacích prostředků. ${ }^{149,150,151}$

Obecným kritériem ${ }^{152}$ pro rozhodnutí, zda policista při zákroku použije mírnějšího či důraznějšího donucovacího prostředku bude skutečnost, zda osoba, proti níž zákrok směřje, klade aktivní ${ }^{153}$ či pasivní odpor. ${ }^{154}$

146 Viz např̀. \58odst. 1 zákona o policii či \22 zákona o obecní policii.

147 Srov. VŠETIČKA, P. Uplatnění správního uvážení a problematika výkladu neurčitých právních pojmů v př́padě bezprostředních zásahů realizovaných Policií České republiky. Časopis pro právní vědu a praxi [online]. 2017, roč. 25, č. 3, s. 493-508 [cit. 12. 10. 2018]. ISSN 493-508. Dostupné z: https://journals. muni.cz/cpvp/article/view/7932

148 Totožné rozdělení donucovacích prostředků na mírnější a důraznější lze dovodit rovněž z aktuální judi-

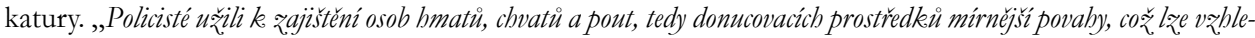
dem ke dané situaci hodnotitjako postup plné odpovídajicípožadavku prïměrenosti soudu ze dne 22. 2. 2017, č. j. 2 As 216/2016-92.

149 „Nasazení pout obvykle neni z blediska čl. 3 Úmluvy problematické, pokud bylo toto opatrení pourìito v souvislosti

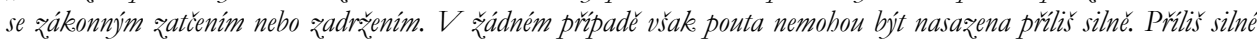
nasaženi (utaženi) pout muiže predstavovat ponižnjici zacházenen". Nález Ústavního soudu ze dne 24. 5. 2016, sp. zn. I. ÚS 1042/15.

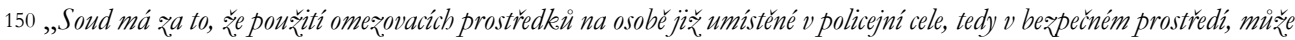
být odivodnèné pouze za zcela výjimě́ných okolnosti". Rozsudek Evropského soudu pro lidská práva ze dne 25. 7. 2013, Kummer proti Ceské republice, sp. zn. 32133/11.

151 Další omezení pozitivní právní úpravy vyplývají z judikatury. Zde je možno zmínit např́klad použití slzotvorného donucovacího prostředku v prostorách policejních cel. ESLP v této souvislosti zaujal stanovisko, že s ohledem na potenciální zdravotní rizika by neměl být slzotvorný donucovací prostředek (pepřový sprej) použiván v uzavřených prostorách. Soud dále konstatoval, že v prostorách policejních cel se jedná o nepřiměřený donucovací prostředek a jeho použití v těchto místech vyhodnotil jako nelidské a ponižující zacházení. Srov. Rozsudek Evropského soudu pro lidská práva ze dne 13. 2. 2014, Tali proti Estonsku, sp. zn. 66393/10.

152 Mimo výše zmiňované zvláštní omezení vyjádřené v $\ 58$ odst. 1 zákona o policii.

153 „Aktivnim odporem lze rozumèt násilné bránèni realizaci služebníbo zákroku“. ŠKODA, J., F. VAVERA a R. ŠMERDA. Zákon o policii s komentárem. 2. vyd. Plzeň: Aleš Čeněk, 2013, s. 201.

154 Srov. Ibid., s. 201. 
Dále lze donucovací prostředky rozdělit na základě objektu jejich působení, a to na:

a) donucovací prostředky, určené primárně pro použití proti jednotlivým osobám, ${ }^{155}$

b) donucovací prostředky, určené primárně pro použití proti skupině osob, ${ }^{156}$

c) donucovací prostředky určené pro použití proti jednotlivým osobám nebo proti skupině osob, ${ }^{157}$

d) donucovací prostředky, určené pro použití proti vozidlu. ${ }^{158}$

Co se týká oprávnění k použití zbraně, zde je třeba říci, že ne ve všech případech je použití zbraně zaměřeno proti osobám. Zákon počítá s použitím zbraně proti:

a) osobě,

b) vozidlu,

c) zvíreti. ${ }^{159,160}$

$\mathrm{V}$ případě, kdy je objektem použití zbraně osoba, je možno tyto situace rozdělit do dvou skupin, a to z hlediska skutečnosti, zda dotyčná osoba vyvijí

a) aktivní či

b) pasivní odpor.

V prvním prrípadě je úřední osoba oprávněna použít zbraň proti osobě, která svým jednáním aktivně ohrožuje její život nebo zdraví anebo život nebo zdraví jiných osob. ${ }^{161}$

$\mathrm{V}$ druhém př́padě je úřední osoba oprávněna použít zbraň proti osobě, která v danou chvíli nevyvíjí bud’ žádnou aktivitu, nebo vyvíjí pouze takový druh aktivity, prostřednictvím které život či zdraví zasahující úřední osoby ani dalších osob ani jiné významné zákonem chráněné zájmy bezprostředně neohrožuje. Jinak řečeno, jedná se o př́ipady, kdy osoba klade pouze tzv. pasivní odpor a to tím způsobem, že se na výzvu zasahující úřední osoby nevzdá či se zdráhá opustit svůj úkryt anebo se pokouší o útěk. ${ }^{162,163}$

\subsubsection{Bezprostredni omezeni}

Bezprostřední omezení mohou být realizována bud' ve vztahu k:
a) osobám nebo
b) věcem.

155 Např. pouta dle $\int 52$ písm. p) zákona o policii.

156 Např. vodní stř́kač dle $\int 52$ písm. k) zákona o policii.

157 Např. obušek a jiný úderný prostředek dle $\int 52$ písm. c) zákona o policii.

158 Např. zastavovací pás dle \52 písm. f) zákona o policii.

159 Viz napr. $\int 56$ odst. 1 zákona o policii.

$160 \mathrm{~V}$ př́padě použití střelné zbraně proti věci ničí (nap̌r. usmrcení divokého zvířete) se dle názoru J. Staši nejedná o bezprostřední zásah, ale úkon obdobný. Srov. STAŠA, J. Úvod do českébo správního práva. 4. vyd. Praha: Policejní akademie České republiky, 2003, s. 86.

161 Srov. např. $\int 56$ odst. 1 písm. a), d), e) a g) zákona o policii.

162 Srov. např. $\int 56$ odst. 1 písm. b) a c) zákona o policii.

$163 \mathrm{~V}$ tomto prípadě je ovšem nezbytnou podmínkou použití zbraně skutečnost, že tato osoba byla zasahující úřední osobou (či jiným oprávněným orgánem) označena za tzv. nebezpečného pachatele. 
Bezprostrední omezení realizovaná ve vztahu k osobám jsou neoddělitelně spjata s faktickými pokyny, a to v tom smyslu, že tvoří jejich obsah. Jinak řečeno, faktické pokyny představují formu a bezprostřední omezení obsah úkonu. $V$ tomto prrípadě jejich působení spočívá v omezení práv a svobod osob, které je autoritativně sděleno v podobě faktického pokynu (př́kazu a zákazu).

Ve vztahu k věcem mají bezprostřední omezení podobu zásahu do činnosti obslužných zařízení, spočívajícího $\mathrm{v}$ jeho dočasném vyřazení z provozu. ${ }^{164} \mathrm{~V}$ tomto př́padě je typickým znakem bezprostředního omezení zpravidla skutečnost, že jsou omezena práva osob, které nejsou původci hrozícího nebezpečí, nebot' se jedná často o protiprávní stavy, které nebyly vyvolány konkrétním původcem ani nebyly vědomě spuštěny. Účelem bezprostředního omezení tedy, na rozdíl od bezprostředního donucení, není eliminace původce nebezpečí či protiprávního jednání, ale zpravidla se jedná o odvracení hrozícího nebezpečí a podle okolností též př́padné odstranění nebo zmírnění jeho následků, přičemž účinky zásahu dopadají na osoby, které se na navození nežádoucího stavu nepodílely.

Schéma č. 4: Členění bezprostředních zásahů z hlediska povahy jejich působení

\begin{tabular}{|c|c|c|}
\hline \multirow{7}{*}{$\begin{array}{l}\text { BEZPROSTŘEDNÍ } \\
\text { ZÁSAHY }\end{array}$} & \multirow{3}{*}{$\begin{array}{l}\text { BEZPROSTŘEDNÍ } \\
\text { OPATŘENÍ }\end{array}$} & Odebrání, odstranění a zničení věci \\
\hline & & $\begin{array}{l}\text { Vstup do obydlí, jiného prostoru nebo } \\
\text { na pozemek }\end{array}$ \\
\hline & & $\begin{array}{l}\text { Prohlídka osoby, prohlídka dopravního } \\
\text { prostředku }\end{array}$ \\
\hline & \multirow{2}{*}{$\begin{array}{l}\text { BEZPROSTŘEDNÍ } \\
\text { DONUCENÍ }\end{array}$} & Použití donucovacích prostředků \\
\hline & & Použití zbraně \\
\hline & \multirow{2}{*}{$\begin{array}{l}\text { BEZPROSTŘEDNÍ } \\
\text { OMEZENÍ }\end{array}$} & $\begin{array}{l}\text { Př́kaz k určitému jednání, zákaz určitého } \\
\text { jednání }\end{array}$ \\
\hline & & Zásah do činnosti obslužného zařízení \\
\hline
\end{tabular}

Zdroj: autor.

164 Nap̌r. dle \29 zákona č. 320/2015 Sb., o Hasičském záchranném sboru České republiky a o změně některých zákonů, ve znění pozdějších předpisů je príislušník hasičského záchranného sboru oprávněn za účelem provedení zásahu vypnout nebo odstavit v nezbytném rozsahu prrívod elektřiny, plynu, tepla, vody nebo jiné zařízení. 


\subsection{Zajišt'ovací úkony}

Smyslem zajišstovacích úkonů je zabezpečit řádný průběh formálního procesu nebo podpora úkonů realizovaných $\mathrm{v}$ rámci výkonu správního dozoru. ${ }^{165}$

Zajišt'ovací úkony představují univerzální právní prostředek, upravený v řadě právních předpisů (náležejících do různých právních odvětví) vyskytujících se napříč právním řádem. Přesto, že je tento právní institut využíván $\mathrm{v}$ mnoha oblastech výkonu veřejné moci, $\mathrm{k}$ jeho realizaci jsou oprávněny orgány (vykonavatelé) veřejné správy, zpravidla př́ślušníci ozbrojených bezpečnostních sborů (nejčastěji prríslušníci policie). Z tohoto důvodu je namístě řadit zajištovací úkony mezi správně-právní činnosti, respektive formy realizace veřejné správy, a to i přesto, že jejich prostřednictvím je zajišt’ován řádný průběh nejen správního, ale též například trestního či civilního soudního řízení.

Z tohoto hlediska je možno zajišt'ovací úkony rozdělit na ty, jež realizuje př́ślušný orgán veřejné správy na základě vlastního rozhodnutí, v souvislosti s plněním svých úkolů, a na ty, jež př́slušný orgán veřejné správy realizuje na žádost jiného orgánu veřejné moci. V této souvislosti je možno hovořit o zajišst'ovacích úkonech realizovaných ze strany orgánů veřejné správy bud' jako o:

a) autonomních ${ }^{166}$ nebo

b) vyžádaných. ${ }^{167}$

Zajišt'ovací úkony mohou být ze strany orgánů veřejné správy realizovány bud' ve vztahu k:

a) osobám, nebo

b) věcem.

Zajišt'ovací úkony se mohou v rámci činnosti orgánů veřejné správy vyskytnout bud' samostatně, anebo $\mathrm{v}$ návaznosti či společně s bezprostředními zásahy, které jim často předchází, či jsou uskutečněny $\mathrm{v}$ jejich průběhu. ${ }^{168}$ Nicméně realizace zajišt’ovacích úkonů nemusí být vždy nutně spojena s fyzickým donucením. Naproti tomu faktické pokyny, uskutečněné nejčastěji v podobě poučení o právech a povinnostech osoby omezené na svobodě, jakož i informace o právních důvodech zajištění, spojené s výzvou

165 Srov. HENDRYCH, D. a kol. Správni právo. Obecná cást. 9. vyd. Praha: C. H. Beck, 2016, s. 189.

166 Např. předvedení osoby za účelem podání vysvětlení dle $\int 61$ odst. 5 zákona o policii.

167 Např̀ předvedení osoby dle $\int 52$ občanského soudního řádu nebo předvedení osoby dle čl. 27 jednacího řádu vyšetřovací komise Poslanecké sněmovny Parlamentu České republiky, publikovaného jako prríloha č. $1 \mathrm{k}$ zákonu o jednacím řádu Poslanecké sněmovny.

168 Např̀ použití donucovacích prostředků v podobě hmatů a chvatů dle $\int 52$ písm. a) zákona o policii proti osobě, která se dopustila protiprávního jednání a její následné zajištění z důvodu obavy, že bude v protiprávním jednání pokračovat dle \26 odst. 1 písm. f) zákona o policii. 
k dobrovolnému podrobení se úkonu (např. vydání zbraně či následování úřední osoby do sídla úřadu), jsou obligatorní součástí zajišt'ovacích úkonů. ${ }^{169}$

Zajišt'ovací úkony učiněné ve vztahu $\mathrm{k}$ věcem nepředstavují tak intenzivní zásah do právních poměrů adresátů veřejné správy jako bezprostřední zásahy (zejména bezprostřední donucenî). Na druhou stranu zajišt'ovací úkony uskutečněné vưči osobám, jsou, vzhledem k omezení jejich svobody, co do intenzity s důsledky bezprostředních zásahů srovnatelné. ${ }^{170}$

S ohledem na povahu pozitivního zákonného vyjádření rozděluje J. Staša zajišstovací úkony na:

a) specifické171 a

b) nespecifické. ${ }^{172}$

V této souvislosti by bylo možno zajišt'ovací úkony rozlišovat též na:

a) pojmenované ${ }^{173}$ a

b) nepojmenované. ${ }^{174}$

Doba možného trvání jednotlivých zajišt'ovacích úkonů (spojených s omezením osobní svobody) upravených v rámci českého právního řádu se liší. V některých př́ípadech zákonodárce stanoví maximální dobu jejich trvání, která nemůže být překročena, zatímco v jiných případech je doba zajištění vázána na dobu trvání úkonu, za účelem jehož uskutečnění bylo zajištění realizováno.

169 Mezi zajišt'ovacími úkony a faktickými pokyny existuje obecně velice úzký vzájemný vztah. Např́klad předvedení osoby (zajišt'ovacímu úkonu) předchází zpravidla její předvolání (faktický pokyn). Realizace zajišt'ovacího úkonu (např. předvedenî) má tedy často podobu následku neuposlechnutí faktického pokynu (nap̌r. nedostavení se k př́islušnému orgánu na př̀edvolání).

170 „Základním východiskem úvah Ústavního soudu je skutečnost, že omez̨eni osobni svobody v podobè zadržení, zatčení, uvaleni vazby či jiné formy detence nebo uvěznèni stavi osobu do pozice určité bezbrannosti". Nález Ústavního soudu ze dne 17. 10. 2017, sp. zn. II. ÚS 1398/17.

171 Specifické zajišt'ovací úkony musí být vymezeny taxativně. Srov. HENDRYCH, D. a kol. Spráuní právo. Obecná část. 9. vyd. Praha: C. H. Beck, 2016, s. 189.

172 Nespecifické zajišt'ovací úkony slouží k opatřování podkladů v rámci řízení před správním orgánem nebo při výkonu správního dozoru. Např́klad povinnost osoby, která má u sebe listinu nebo věc potřebnou k provedení důkazu, tuto listinu nebo věc na vyžádání správního orgánu prèložit nebo strpět její ohledání na místě dle $\int 53$ a 54 správního řádu nebo oprávnění kontrolního orgánu provádět v rámci kontrolní činnosti kontrolní nákupy a odebírat vzorky dle $\int 8$ písm. b) kontrolního řádu. Srov. Ibid., s. 189.

173 Např́klad ,zajištění osoby“ dle \26 zákona o policii.

174 Např́klad „práva kontrolujícího“ (kontrolního orgánu) uvedená v \8 kontrolního řádu. 
Z hlediska zákonného stanovení doby jejich trvání je možno rozlišovat zajišt'ovací úkony na:

a) dobu určitou, ${ }^{175}$

b) dobu neurčitou. ${ }^{176,177}$

\section{Závěr}

Závěrem lze jednoznačně konstatovat potvrzení v úvodu stanovené hypotézy, tedy že faktické úkony je možno členit podrobnějším způsobem než s jakým se lze v rámci nauky setkat. Ten samý závěr lze ovšem vyvodit i ohledně ostatních neformálních projevů veřejné správy, zvláště pak pokud jde o tzv. příbuzné úkony, v jejichž případě se jedná o dosud z velké části neprobádanou problematiku, jejíž podrobnější zpracování by ovšem přesahovalo záměr předkládaného příspěvku.

Mimo zpracování stěžejního tématu, tedy problematiky systemizace faktických úkonů, jsem pokládal za vhodné provést analýzu právní povahy, jakož i obecných znaků a vlastností, jež jsou společné pro všechny (či alespoň drtivou většinu) neformálních projevů veřejné správy, majících povahu správně-právních činností realizovaných ze strany orgánů veřejné správy.

V souvislosti se samotným členěním faktických úkonů je možno vyslovit závěr, že řada konvergenčních prvků, významných pro rozdělení předmětné matérie do jednotlivých skupin, zůstávala doposud ze strany vědy správního práva bez povšimnutí. To se týká především skupiny faktických úkonů označovaných jako tzv. bezprostřední zásahy. $\mathrm{V}$ tomto ohledu věřím, že má práce alespoň dílčím způsobem přispěla $\mathrm{k}$ rozvoji vědeckého poznání na tomto poli. Naopak, pokud jde o skupinu faktických úkonů označovanou z právně-teoretického hlediska jako tzv. faktické pokyny, zde se lze v rámci relevantní literatury setkat s poměrně propracovanou systematikou, tudíž jsem z části navazoval na obecně přijímané závěry nauky, a to ve snaze je dále rozšíríit.

Závěrem je možno poznamenat, že naplnění cíle předkládaného prríspěvku má význam především pro další rozvoj vědeckého poznání v této oblasti, nebot' smyslem podrobné systemizace faktických úkonů je především celkové zpřehlednění této značně rozsáhlé a v mnoha ohledech nesourodé matérie, přičemž přijaté závěry by nepochybně bylo možno využít též pro pedagogické účely.

$175 \mathrm{~V}$ tomto př́padě se bude jednat zpravidla o tzv. pojmenované zajišt’ovací instituty. Zákon v těchto př́padech závazně stanoví maximální možnou dobu trvání omezení osobní svobody. Viz např. $\ 26$ zákona o policii.

176 Typicky se bude jednat o předvedení, jež je v rámci platné právní úpravy koncipováno jako zajišt’ovací institut, jehož účelem je zajištění řádného průběhu (správního, soudního či jiného) rízenení. Doba trvání předvedení je tedy závislá na době trvání procesních úkonů, za účelem jejichž uskutečnění bylo předvedení realizováno (napríklad výslech svědka). Nicméně v praxi se zpravidla nebude jednat o dobu delší než (maximálně) několik hodin.

177 Obecné podmínky omezení osobní svobody ze strany orgánů veřejné správy, uskutečněné bez rozhodnutí soudu, upravuje čl. 8 Listiny. 